\title{
Validation strategies for antibodies targeting modified ribonucleotides
}

\author{
FRANZISKA WEICHMANN, ${ }^{1}$ ROBERT HETT, ${ }^{1}$ ALOYS SCHEPERS, ${ }^{2}$ TAKU ITO-KUREHA, ${ }^{3}$ ANDREW FLATLEY, ${ }^{2}$ \\ KAOUTHAR SLAMA ${ }^{4}$ FLORIAN D. HASTERT, ${ }^{5}$ NICHOLAS B. ANGSTMAN, ${ }^{6}$ M. CRISTINA CARDOSO, ${ }^{5}$ \\ JULIAN KÖNIG, ${ }^{7}$ STEFAN HÜTTELMAIER, ${ }^{8}$ CHRISTOPH DIETERICH, ${ }^{9}$ STEFAN CANZAR, ${ }^{6}$ MARK HELM, ${ }^{4}$ \\ VIGO HEISSMEYER, ${ }^{3,10}$ REGINA FEEDERLE, $^{2}$ and GUNTER MEISTER ${ }^{1}$ \\ ${ }^{1}$ Regensburg Center for Biochemistry, Laboratory for RNA Biology, University of Regensburg, 93053 Regensburg, Germany \\ ${ }^{2}$ Institute for Diabetes and Obesity, Monoclonal Antibody Core Facility and Research Group, Helmholtz Zentrum München, German Research \\ Center for Environmental Health (GmbH), 85764 Neuherberg, Germany \\ ${ }^{3}$ Institute for Immunology, Biomedical Center of the Ludwig-Maximilians-University München, 82152 Planegg-Martinsried, Germany \\ ${ }^{4}$ Institute of Pharmacy and Biochemistry, Johannes-Gutenberg-Universität Mainz, 55128 Mainz, Germany \\ ${ }^{5}$ Cell Biology and Epigenetics, Technische Universität Darmstadt, 64287 Darmstadt, Germany \\ ${ }^{6}$ Gene Center, Ludwig-Maximilians-University Munich, 81377 Munich, Germany \\ ${ }^{7}$ Institute of Molecular Biology (IMB), Ackermannweg 4, 55128 Mainz, Germany \\ ${ }^{8}$ Institute of Molecular Medicine, Section for Molecular Cell Biology, Faculty of Medicine, Martin Luther University Halle-Wittenberg, \\ Charles Tanford Protein Centre, 06120 Halle, Germany \\ ${ }^{9}$ Bioinformatics and Systems Cardiology, Klaus Tschira Institute for Integrative Computational Cardiology and Department of Internal \\ Medicine III, University Hospital Heidelberg, 69120 Heidelberg, Germany \\ ${ }^{10}$ Research Unit Molecular Immune Regulation, Helmholtz Zentrum München, Deutsches Forschungszentrum für Gesundheit und Umwelt \\ (GmbH), 81377 Munich, Germany
}

\begin{abstract}
Chemical modifications are found on almost all RNAs and affect their coding and noncoding functions. The identification of $\mathrm{m}^{6} \mathrm{~A}$ on $\mathrm{mRNA}$ and its important role in gene regulation stimulated the field to investigate whether additional modifications are present on mRNAs. Indeed, modifications including $m^{1} A, m^{5} C, m^{7} G, 2^{\prime}-O M e$, and $\Psi$ were detected. However, since their abundances are low and tools used for their corroboration are often not well characterized, their physiological relevance remains largely elusive. Antibodies targeting modified nucleotides are often used but have limitations such as low affinity or specificity. Moreover, they are not always well characterized and due to the low abundance of the modification, particularly on mRNAs, generated data sets might resemble noise rather than specific modification patterns. Therefore, it is critical that the affinity and specificity is rigorously tested using complementary approaches. Here, we provide an experimental toolbox that allows for testing antibody performance prior to their use.
\end{abstract}

Keywords: monoclonal antibodies; affinity; $\mathrm{m}^{6} \mathrm{~A} ; \mathrm{m}^{5} \mathrm{C}$; validation; base modifications

\section{INTRODUCTION}

RNA molecules are composed of nucleotides carrying the four bases adenine (A), guanine $(\mathrm{G})$, cytosine $(\mathrm{C})$, and uracil (U). Soon after the discovery of RNAs with noncoding functions such as transfer RNAs (tRNAs) or ribosomal RNAs (rRNAs), it became evident that RNAs can be heavily modified and these modifications are important for their structures and functions (Littlefield and Dunn 1958; Bergquist and Matthews 1962). Bases can be chemically modified to gain or lose specific biophysical properties. Such mod-

Corresponding author: gunter.meister@ur.de

Article is online at http://www.rnajournal.org/cgi/doi/10.1261/rna. 076026.120 . ifications may, for example, lead to changes in RNA basepairing or RNA folding (Motorin and Helm 2011; Polikanov et al. 2015). In addition, some modifications could generate binding platforms for specialized RNA binding proteins (RBPs). A prominent example for modified bases is pseudouridine $(\Psi)$, which is present in rRNA, tRNA, and also mRNA (Zhao et al. 2017). The modification reactions are catalyzed by specialized RNA-protein complexes (RNPs)

(C) 2020 Weichmann et al. This article is distributed exclusively by the RNA Society for the first 12 months after the full-issue publication date (see http://rnajournal.cshlp.org/site/misc/terms.xhtml). After 12 months, it is available under a Creative Commons License (Attribution-NonCommercial 4.0 International), as described at http:// creativecommons.org/licenses/by-nc/4.0/. 
containing box H/ACA small nucleolar RNAs (snoRNAs) and the associated catalytic subunit dyskerin (snoRNPs) (Matera et al. 2007).

The recent developments in RNA sequencing technologies revealed that modifications are widespread and found in almost all RNAs including mRNAs (Helm and Motorin 2017). An example for an abundant modification found in mRNAs is N6-methyl-Adenosine ( $m^{6} \mathrm{~A}$ ) (Dominissini et al. 2012; Meyer et al. 2012). This modification is generated on mRNAs by the METTL3-METTL14 enzyme complex (Batista et al. 2014; Liu et al. 2014; Meyer and Jaffrey 2017). A multitude of different $m^{6} A$ methylation patterns have been reported and thus many cellular functions are associated with this modification (Fu et al. 2014; Maity and Das 2016). For example, $m^{6} A$ is enriched around stop codons, on 3'-UTRs and in large exons (Ke et al. 2015; Yue et al. 2015). In the nucleus, $m^{6} \mathrm{~A}$ modification accelerates turnover of modified transcripts but seems to be dispensable for splicing (Ke et al. 2017). In contrast, it has been reported that hnRNPG binds RNA polymerase II and $\mathrm{m}^{6} \mathrm{~A}$ modifications on nascent pre-mRNAs leading to changes in splicing patterns (Zhou et al. 2019). In the cytoplasm, $\mathrm{m}^{6} \mathrm{~A}$ promotes cap-independent translation initiation by direct recruitment of initiation factors (Meyer et al. 2015; Coots et al. 2017; Yang et al. 2017).

In addition to $\mathrm{m}^{6} \mathrm{~A}$, a number of other mRNA modifications have been reported. $M^{1} A$ (N1-methyladenosine) has recently been identified on cytosolic and mitochondrial mRNA but probably at low frequency (Li et al. 2017; Safra et al. 2017). $\Psi$ has been profiled and found that mRNAs also carry this modification (Carlile et al. 2014; Lovejoy et al. 2014; Schwartz et al. 2014; Li et al. 2015). $\mathrm{M}^{5} \mathrm{C}$ (5-methylcytosine), a common modification found on DNA, has been reported on mRNAs as well (Squires et al. 2012; Amort et al. 2017; Legrand et al. 2017; Huang et al. 2019) and this phenomenon appears to be conserved in Archaea (Edelheit et al. 2013). In addition, noncoding RNAs have also been found to contain $\mathrm{m}^{5} \mathrm{C}$ modifications (Hussain et al. 2013; Trixl and Lusser 2019). Most of these $\mathrm{m}^{5} \mathrm{C}$ studies utilized bisulfite-sequencing protocols, which are widely used for studying DNA $\mathrm{m}^{5} \mathrm{C}$ modifications and found very few to thousands of methylated sites on mRNAs. Other studies used $m^{5} \mathrm{C}$-specific antibodies to validate bisulfite-sequencing results. However, available antibodies were often selected for DNA specificity and their applicability for single stranded RNA is unclear.

It is likely that the abovementioned examples are more the tip of the iceberg rather than a complete picture of mRNA base modifications. $M^{6} A$ is the best-studied mRNA modification to date and this is due to the rather high abundance and the availability of antibodies against this modification. Some of them have been developed a long time ago and proved to be invaluable tools for the analysis of $m^{6} \mathrm{~A}$ on mRNA (e.g., Bringmann and
Luhrmann 1987). Antibodies against other base modifications have been generated but low modification abundance as well as a lack of thorough validation led to rather vague results in RNA-seq experiments (Grozhik et al. 2019; Helm et al. 2019). Thus, a rigorous validation of base-specific antibodies for each individual assay that is applied is a critical prerequisite for the generation of conclusive and trustable data (Feederle and Schepers 2017).

To help solving this fundamental problem, we developed a panel of assays for antibody validation. In addition, we generated our own monoclonal antibodies against $m^{6} \mathrm{~A}, \mathrm{~m}^{5} \mathrm{C}, \mathrm{m}_{2}{ }^{6} \mathrm{~A}$ (N6, N6-dimethyladenosine), and $\Psi$ to prove the applicability of our validation and testing pipeline (Erlanger and Beiser 1964). We used a number of biochemical and biophysical assays and measurements ranging from $K_{d}$ and enrichment factor determination to immunofluorescence and FACS analysis. Our study provides a detailed characterization platform for antibodies against base modifications helping to define quality standards for these widely used research tools. (See Table 1)

\section{RESULTS}

\section{Generation of monoclonal antibodies against modified nucleosides}

For the establishment and testing of different validation methods, large quantities of antibodies are required. Therefore, we set out to generate our own monoclonal antibodies against specific base modifications, which were validated during the course of this study. We coupled individual nucleosides to a carrier protein and used the conjugate for immunization. The association to a carrier is necessary, as single nucleosides alone are too small to produce an efficient immune response. Ovalbumin (OVA) was used as an appropriate immunogenic carrier protein for immunization (Plescia and Braun 1967). To couple the modified nucleosides $\mathrm{m}^{6} \mathrm{~A}, \mathrm{~m}^{5} \mathrm{C}, \mathrm{m}_{2}{ }^{6} \mathrm{~A}$, and $\Psi$, a modified Erlanger-Beiser protocol was applied (Fig. 1A, see Materials and Methods for details). The first chemical reaction oxidizes and opens the ribose ring between the $2^{\prime}$ and $3^{\prime}$ position. An amino group of a lysine side chain, for example, can now efficiently react with the nucleoside leading to covalent coupling to the protein (Fig. 1B). To validate and estimate coupling efficiencies, photometric analyses were performed (Fig. 1C). OVA alone peaks at a wavelength of about $280 \mathrm{~nm}$ (Fig. 1C, blue lines in all panels). Generally, the nucleoside-OVA conjugation shifts the OVA peak (purple lines) toward the free nucleosides (red lines). Coupling of $\mathrm{m}^{6} \mathrm{~A}$ (purple graph, panel I) and $\Psi$ (purple graph, panel II) shifted the peaks toward the peak of $m^{6} \mathrm{~A}$ or $\Psi$ alone (Fig. 1C, red graphs). For $m^{5} \mathrm{C}$ and $\mathrm{m}_{2}{ }^{6} \mathrm{~A}$ (panels III and IV) shifts were less pronounced since the individual components peak at a rather small window. Based 
TABLE 1. Summary of antibody validation results

\begin{tabular}{|c|c|c|c|c|c|c|c|}
\hline Modification & Antibody clone & Apparent $K_{D}$-value & RNA-IP & TLC & IF & Cross-link & FACS \\
\hline \multirow[t]{4}{*}{$\mathrm{m}^{6} \mathrm{~A}$} & $13 G 2$ & + & n.a. & ++ & n.a. & n.a. & n.a. \\
\hline & 11D11 & +++ & ++ & ++ & - & + & ++ \\
\hline & 9B7 & +++ & ++ & ++ & ++ & +++ & +++ \\
\hline & $19 B 7$ & n.a. & + & n.a. & +++ & +++ & +++ \\
\hline \multirow[t]{3}{*}{$m^{5} \mathrm{C}$} & 31B10 & ++ & n.a. & - & - & n.a. & n.a. \\
\hline & $28 \mathrm{~F} 6$ & ++ & n.a. & + & - & n.a. & n.a. \\
\hline & $32 \mathrm{E} 2$ & +++ & +++ & +++ & +++ & +++ & n.a. \\
\hline \multirow[t]{2}{*}{$\Psi$} & $26 \mathrm{H} 5$ & - & n.a. & n.a. & n.a. & n.a. & n.a. \\
\hline & $27 \mathrm{C} 8$ & - & - & + & n.a. & ++ & n.a. \\
\hline $\mathrm{m}_{2}{ }^{6} \mathrm{~A}$ & $60 \mathrm{G} 3$ & ++ & ++ & n.a. & n.a. & + & n.a. \\
\hline
\end{tabular}

$K_{\mathrm{D}}$, dissociation constant; IP, immunoprecipitation; TLC, thin layer chromatography-experiment; IF, immunofluorescence; FACS, fluorescence-activated cell sorting; + , medium performance in the experiment; ++ , good performance in the experiment; +++ , very good performance in the experiment; n.a., not analyzed.

on the peak intensities, coupling efficiencies were estimated to $20 \%$ (data not shown). Similar results were obtained for coupling of the nucleosides to bovine serum albumin (BSA) as carrier protein (data not shown).

OVA-conjugated nucleosides carrying $\mathrm{m}^{5} \mathrm{C}, \mathrm{m}^{6} \mathrm{~A}, \mathrm{~m}_{2}^{6} \mathrm{~A}$, and $\Psi$, were used to immunize rats and mice (Fig. 1D). Six to eight weeks after primary immunization, one boost injection was given and the immunized animals were sacrificed $3 \mathrm{~d}$ later. After fusion of splenic $B$ cells and the myeloma cell line, all cells were evenly distributed in 96well plates and hybridoma cells were selected. All outgrowing hybridoma cells were first screened in ELISA experiments for the expression of IgG antibodies specifically binding the respective modified nucleoside either as BSA-conjugates or as biotinylated oligonucleotides (Fig. 1D, detection ELISA I/II). Capture ELISA experiments using BSA-conjugated nucleosides were performed to identify those supernatants containing IgG antibodies that are potentially useful for immunoprecipitation experiments (Fig. 1D, capture ELISA). Unmodified oligonucleotides were included in all screenings as negative controls. Monoclonal hybridoma cell lines directed against $m^{6} \mathrm{~A}, m^{5} \mathrm{C}, \mathrm{m}_{2}{ }^{6} \mathrm{~A}$, and $\Psi$ were established and used for further validation studies. (See Table 1.)

\section{Determination of dissociation constants $\left(K_{d}\right)$}

In order to estimate the general performance of the antibodies in functional assays, we determined their affinities to free nucleosides (Fig. 2). Equimolar mixtures of modified and unmodified nucleosides were incubated with the respective antibody. The mixture was subsequently centrifuged through a filter allowing molecules $<10 \mathrm{kDa}$ passing through. This procedure separates antibodybound from -unbound nucleosides, which can be used for $K_{d}$ estimations (Fig. 2A). Input samples and filtrates were further analyzed and quantified by HPLC.
$K_{d}$ values were calculated via Scatchard plots (Fig. 2B; Supplemental Fig. 1) and a binding model was generated using data fitting (Fig. 2C-F; Supplemental Fig. 1; see Material and Methods for experimental details and $K_{d}$ calculations). Using this method, we estimated the $K_{d}$ of the $\alpha-\mathrm{m}^{6} \mathrm{~A}$ clone $9 \mathrm{~B} 7$ to $0.55 \mu \mathrm{M}$, clone 11D11 to $0.59 \mu \mathrm{M}$ and clone $13 \mathrm{G} 2$ to $1.92 \mu \mathrm{M}$ (Fig. 2G). We next tested antibody clones against $\mathrm{m}^{5} \mathrm{C}$ and identified affinities in a similar range with clone 32E2 showing the highest affinity of $0.39 \mu \mathrm{M}$ (Fig. 2D,G). Also, $\alpha-\mathrm{m}_{2}{ }^{6} \mathrm{~A}$ clone $60 \mathrm{G} 3 \mathrm{had}$ a rather high affinity to the modified nucleoside (Fig. 2E,G), while two clones directed against $\Psi(26 \mathrm{H} 5$ and $27 \mathrm{C} 5)$ showed only moderate affinities (Fig. 2F,G). Our data therefore suggest that most of the tested antibodies have reasonably high affinity in solution (Fig. 2G) at least to their nucleoside antigen and might be useful tools for further functional work.

\section{"Dot blot" analysis}

A common strategy to screen large numbers of hybridoma clones are western blots against antigens spotted onto nitrocellulose membranes-a method commonly referred to as "dot blots." BSA-conjugated nucleosides or oligonucleotides were immobilized and incubated with the respective antibodies. Methylene blue staining served as loading control (Fig. 3A). Indeed, all tested clones (anti$\mathrm{m}^{6} \mathrm{~A} 9 \mathrm{~B} 7$; anti- $\mathrm{m}^{5} \mathrm{C} 32 \mathrm{E} 2$; anti- $\Psi 27 \mathrm{C} 8$ and anti-m ${ }_{2}^{6} \mathrm{~A}$ 60G3) recognized their modified base epitopes while the unmodified base was not detected (Fig. 3B). To evaluate whether antibodies recognize modified bases in a more natural environment, we modified the dot blot approach and spotted modified and unmodified oligonucleotides onto a nylon membrane and incubated it with the antibodies (Fig. 3C). A widely used commercially available antibody against $\mathrm{m}^{6} \mathrm{~A}$ (Synaptic Systems) was included for comparison. Although nylon membranes generated 
A

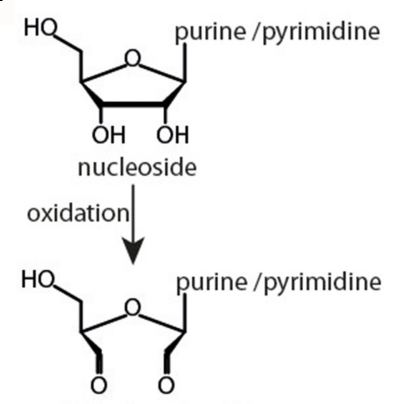

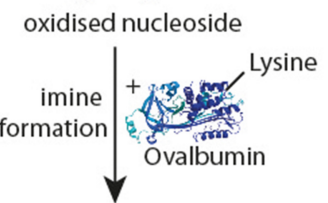

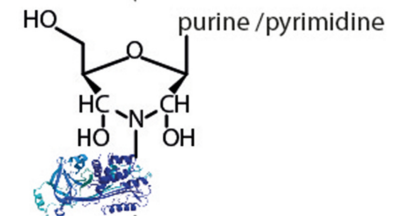

reduction \& gelfiltration purification

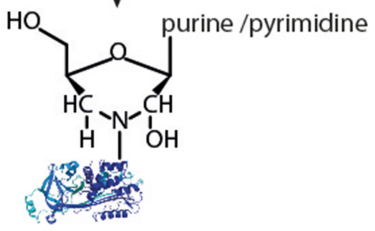

B

C

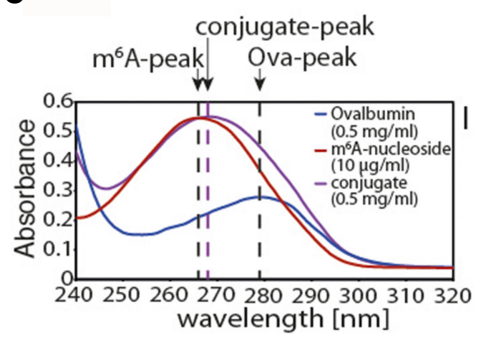

conjugate-peak

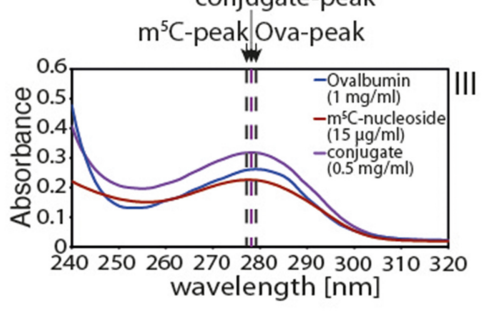

nucleoside

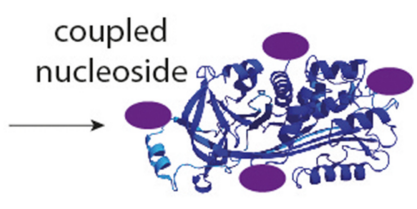

conjugate
,

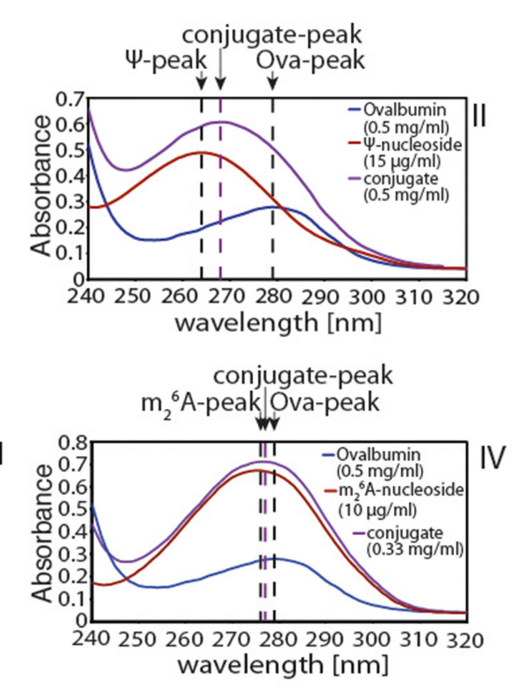

D

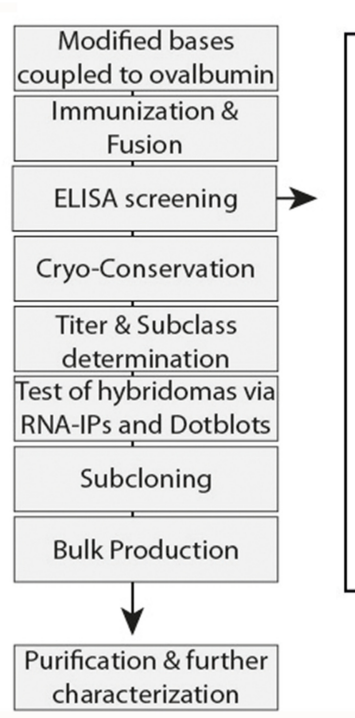

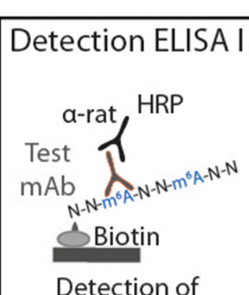

modified bases

Test

$\sum_{N-N-A-N-N-A-N-N}$

No detection of unmodified bases

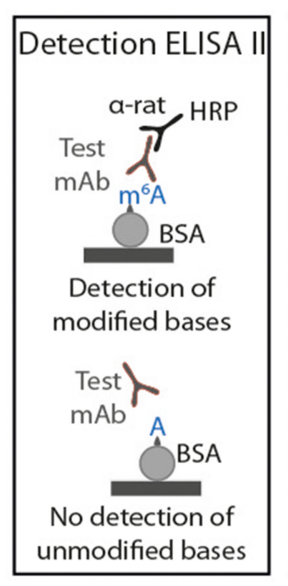

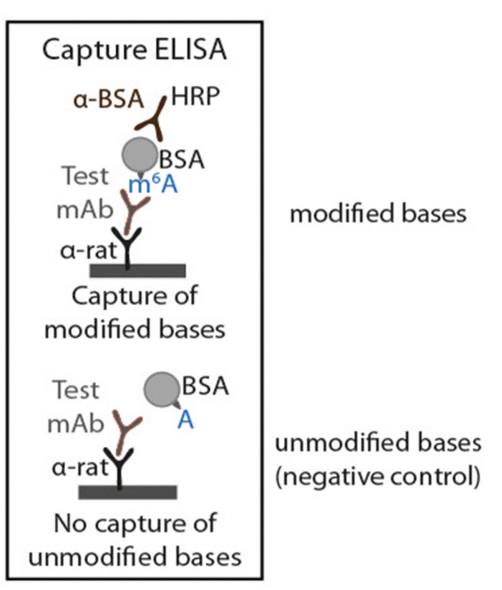

FIGURE 1. Synthesis of antigens for immunization: Coupling of nucleosides to ovalbumin. (A) Scheme for the conjugation reaction of the nucleosides to ovalbumin using the lysine $\mathrm{NH}_{2}$-group as reactive group. After oxidative coupling, the nucleoside no longer has RNA-specific properties, as the ribose ring is destroyed in the course of the reaction. (B) Schematic model of the coupling reaction of nucleoside (red) to ovalbumin (blue) to gain the conjugate (purple). (C) UV spectra of the coupled conjugates (purple) versus free ovalbumin (blue) and free nucleosides (red) are shown. The first spectrum shows $\mathrm{m}^{6} \mathrm{~A}$ coupling followed by the spectra of $\mathrm{m}^{5} \mathrm{C}$, pseudouridine $(\Psi)$, and of $\mathrm{m}_{2}{ }^{6} \mathrm{~A}$. (D) Outline of the generation of monoclonal antibodies against modified bases. Hybridoma cells were tested by detection and capture ELISAs using BSA-coupled nucleosides or biotinylated RNA-DNA-oligo hybrids. 
A
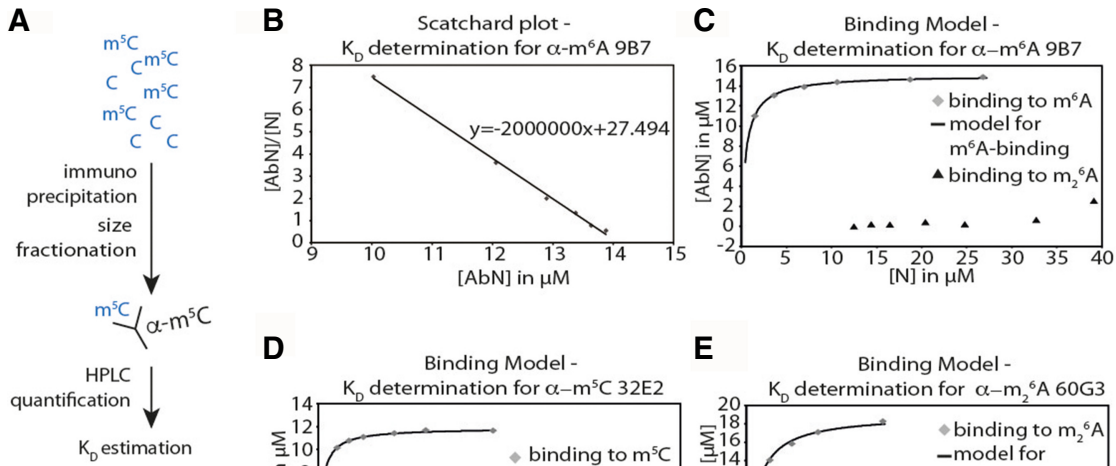

D

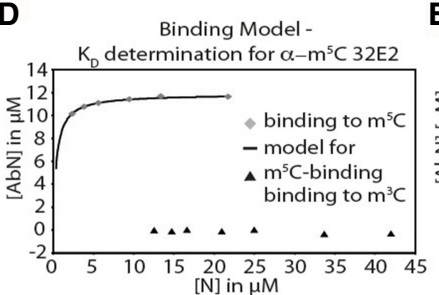

$\mathbf{E}$

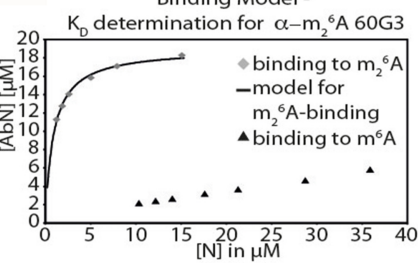

$\mathbf{F}$

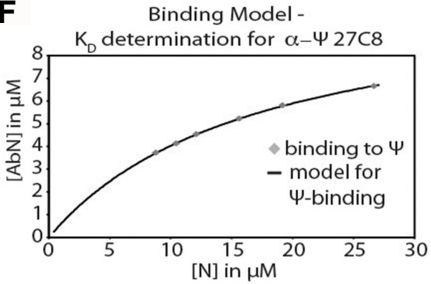

G

\begin{tabular}{|c|ccc|}
\hline \multirow{2}{*}{ Modification } & $\begin{array}{c}\text { Antibody } \\
\text { clone }\end{array}$ & $\begin{array}{c}\text { apparent } \\
\mathrm{K}_{\mathrm{D}} \text {-value } \\
\text { (nucleoside) } \\
{[\mu \mathrm{M}]}\end{array}$ & $\begin{array}{c}\text { control } \\
\text { nucleoside }\end{array}$ \\
\hline \multirow{4}{*}{$\mathrm{m}^{6} \mathrm{~A}$} & $13 \mathrm{G} 2$ & 1.92 & $\mathrm{~A}$ \\
\cline { 2 - 4 } & $11 \mathrm{D} 11$ & 0.59 & $\mathrm{~A}$ \\
\cline { 2 - 4 } & $9 \mathrm{~B} 7$ & $\begin{array}{c}0.55 \\
0.89\end{array}$ & $\begin{array}{c}\mathrm{A} \\
\mathrm{m}_{2}{ }^{6} \mathrm{~A}\end{array}$ \\
& & 0.60 & $\mathrm{~m}^{1} \mathrm{~A}$ \\
\hline \multirow{4}{*}{$\mathrm{m}^{5} \mathrm{C}$} & $31 \mathrm{~B} 10$ & 1.14 & $\mathrm{C}$ \\
\cline { 2 - 4 } & $28 \mathrm{~F} 6$ & 1.5 & $\mathrm{C}$ \\
\hline \multirow{2}{*}{$\Psi$} & $32 \mathrm{E} 2$ & 0.39 & $\mathrm{C}$ \\
& $26 \mathrm{H} 5$ & 38.12 & $\mathrm{U}$ \\
\hline \multirow{2}{*}{$\mathrm{m}_{2}{ }^{6} \mathrm{~A}$} & $27 \mathrm{C} 8$ & 17.18 & $\mathrm{U}$ \\
\hline & $60 \mathrm{G} 3$ & 0.89 & $\mathrm{~A}$ \\
& & 1.15 & $\mathrm{~m}^{6} \mathrm{~A}$ \\
\hline
\end{tabular}

FIGURE 2. Determination of $K_{D}$-values of antibodies against base modifications. (A) Schematic outline of the experiment to determine $K_{D}$ values of the antibodies. An equimolar mixture of modified and unmodified nucleotides was incubated with the respective antibodies tested and centrifugated through a filter with a cutoff, allowing free nucleotides but not nucleoside-antibody complexes to pass through. HPLC quantification of bound and unbound nucleosides were used for $K_{D}$ estimation. (B) Example for a Scatchard plot for antibody $\alpha-m^{6} A$ 9B7. (C) Binding model for antibody $m^{6} A 9 B 7$ shows the slow convergence toward saturation of the antibody binding capacity for the binding to $\mathrm{m}^{6} \mathrm{~A}$ nucleosides (gray squares). The black triangles depict the binding to $\mathrm{m}_{2}{ }^{6} \mathrm{~A}$ nucleosides. (D) Binding model of antibody $\mathrm{m}^{5} \mathrm{C}$ $32 \mathrm{E} 2$, showing binding to $\mathrm{m}^{5} \mathrm{C}$ nucleosides (squares) and to $\mathrm{m}^{3} \mathrm{C}$ (triangles). (E) Estimation of the $K_{\mathrm{D}}$-value for antibody $\mathrm{m}_{2}{ }^{6} \mathrm{~A} 60 \mathrm{G} 3$, using a binding model based on $\mathrm{m}_{2}{ }^{6} \mathrm{~A}$ (squares) or $\mathrm{m}^{6} \mathrm{~A}$ nucleoside binding (triangles). ( $F$ ) The binding model for $\alpha-\Psi$ antibody $27 \mathrm{C} 8$ was performed as described using $\Psi$ nucleosides. For additional Scatchard plots and binding models for the antibody $K_{\mathrm{D}}$-values listed in Figure 2G, see Supplemental Figure 1. (G) Overview of the $K_{D}$-values of the different tested antibody clones against $m^{6} \mathrm{~A}, \mathrm{~m}^{5} \mathrm{C}, \Psi$, and $\mathrm{m}_{2}{ }^{6} \mathrm{~A}$. The last row indicates the respective nucleoside that was used for estimating the $K_{\mathrm{D}}$-value.

known how specific they enrich modified RNAs compared to their unmodified counterparts adding uncertainty to many of these experiments. Therefore, we established two assays allowing for the determination of enrichment factors of modification-specific antibodies (Fig. 4). In a first approach, we used chemically synthesized oligonucleotides containing either modified or unmodified bases $\left(m^{6} \mathrm{~A}, m^{5} \mathrm{C}, \Psi, \mathrm{m}_{2}{ }^{6} \mathrm{~A}\right)$. RNAs were ${ }^{32} \mathrm{P}$-labeled, immunoprecipitated using the modification-specific antibodies and enrichments of modified compared to unmodified oligonucleotides were determined (Fig. 4B-F). The $\alpha-m^{6} A$ clone $9 B 7$ enriched $m^{6} A$ modified RNA by approximately fivefold and is highly specific for $\mathrm{m}^{6} \mathrm{~A}$ (Fig. 4B, left panel). The widely used commercially available $\mathrm{m}^{6} \mathrm{~A}$-specific polyclonal antibody from Synaptic Systems showed moderate cross-reactivity with $m^{5} \mathrm{C}$ and $m_{2}{ }^{6} \mathrm{~A}$ in these experiments (Fig. 4B, right panel). Furthermore, we tested whether the affinity of the antibodies differ when $m^{6} \mathrm{~A}$ is within its natural $\mathrm{RACH}$ motif or when total RNA is added to simulate RIP experiments under realistic conditions (Supplemental Fig. 3A). Indeed, under these conditions, both the $\mathrm{m}^{6} \mathrm{~A}$-specific antibody $9 \mathrm{~B} 7$ and the one from Synaptic Systems efficiently enriched modified RNA. The $\alpha-m^{5} \mathrm{C}$ clone $32 \mathrm{E} 2$ highly specifically enriched the $\mathrm{m}^{5} \mathrm{C}$-modified RNA, other tested modifications were not recognized (Fig. $4 \mathrm{C}$ ). $\mathrm{m}^{5} \mathrm{C}$-specific antibodies from Diagenode or Cell Signaling only moderately enriched $\mathrm{m}^{5} \mathrm{C}$-containing RNAs, most likely due to the fact that they were raised stronger antibody background, the tested hybridoma clones readily detected the modified but not the unmodified oligonucleotide with the exception of anti- $\Psi 27 \mathrm{C} 8$, which did not work in this assay. This further underscores the need of different validation approaches to estimate antibody performance.

\section{Determination of modified RNA enrichment}

Although antibodies against RNA modifications are widely used in genome-wide profiling studies, it is often not against modified DNA (Fig. 4D). A similar experiment was performed with the $\alpha-\Psi$ antibody 27C8 (Fig. 4E). The antibody enriched $\Psi$-containing RNA by approximately fourfold but seems to enrich $\mathrm{m}^{5} \mathrm{C}$ even more. It is therefore not specific enough and the use of this antibody is clearly limited. Finally, we analyzed the $m_{2}{ }^{6} \mathrm{~A}$-specific antibody clone $60 \mathrm{G} 3$ (Fig. 4F). This antibody enriches $\mathrm{m}_{2}{ }^{6} \mathrm{~A}$-modified RNA eightfold and does not cross-react with any other modification that we tested. Of note, even the structurally highly similar $\mathrm{m}^{6} \mathrm{~A}$ modification seems to be discriminated by this antibody. 


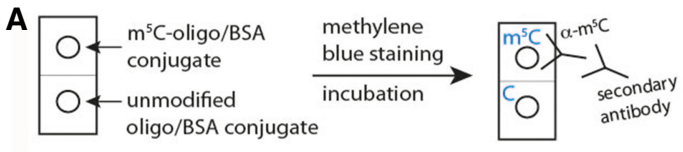

B

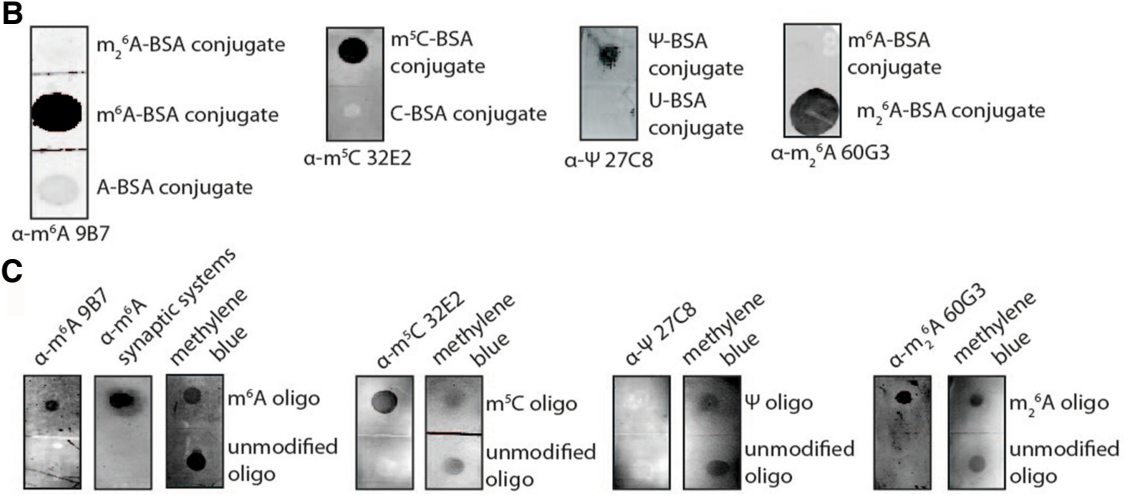

FIGURE 3. Antibody specificity against base modifications using dot blot assays. (A) Scheme of the dot blot experimental setup. Unmodified/modified BSA conjugates or oligonucleotides $\left(\mathrm{m}^{5} \mathrm{C}\right.$ or $\mathrm{C}$ as examples) were spotted on a nylon membrane. After cross-linking and blocking, the membrane was incubated with the primary and secondary antibodies. Methylene blue stains nucleic acids and was used as a loading control. (B) Dot blot experiments, for which modified and unmodified BSA-nucleoside conjugate was used to assess the specificity of the antibodies $\alpha-m^{6} A$ 9B7, $\alpha-m^{5} C 32 E 2, \alpha-\Psi 27 C 8$, and $\alpha-m_{2}{ }^{6} A$ 60G3. For $m^{6} A$, also the $m_{2}{ }^{6} A-B S A$ conjugate was spotted to investigate specificity between the two very similar modifications. (C) Dot blot experiments using a modified and a nonmodified 12-mer RNA oligonucleotide as negative control. The antibody staining is shown on the left and the methylene blue staining as a loading control on the right. The dot blots for the antibodies $\alpha-\mathrm{m}^{6} \mathrm{~A} 9 \mathrm{~B} 7$ and Synaptic Systems, $\alpha-m^{5} \mathrm{C} 32 \mathrm{E} 2, \alpha-\Psi 27 \mathrm{C} 8$, and $\alpha-\mathrm{m}_{2}{ }^{6} \mathrm{~A} 60 \mathrm{G} 3$, are depicted.

In addition to the RIP experiments described above, we further developed a second approach to determine enrichment factors. In two in vitro transcription reactions, either the modified or the unmodified nucleotide was added (Slama et al. 2019). The modified RNA was transcribed in the presence of $\alpha-{ }^{32} P$-UTP and the unmodified was labeled with $\alpha-{ }^{32}$ P-ATP. Both RNAs were mixed in different ratios and used for immunoprecipitation experiments using the modification-specific antibodies. After washing, the immunoprecipitated RNAs were fully hydrolyzed and the nucleotides were separated by thin layer chromatography (Fig. $4 \mathrm{G})$. Since $\alpha-{ }^{32} \mathrm{P}-\mathrm{UMP}$ can be separated from $\alpha-{ }^{32} \mathrm{P}-\mathrm{AMP}$, the ratio between the two signals can be quantified and used for calculating the enrichment factor of the modified compared to the unmodified RNA. Using this approach, we tested $\alpha-m^{6} A$ 9B7, $\alpha-m^{5} C 32 E 2$ and $\alpha-\Psi 27 C 8$, because these modified nucleotides can be incorporated by $T 7$ polymerase-mediated in vitro transcription. We tested two different conditions with $1 \%$ or $50 \%$ modified nucleotides being added to the in vitro transcription reaction. The $\alpha$ $\mathrm{m}^{6} \mathrm{~A} 9 \mathrm{~B} 7$ antibody enriched the modified RNA moderately by 1.5 -fold (Fig. $4 \mathrm{H}$ ), which is similar to the enrichment factor of 1.5 to twofold by the commercial antibody from Synaptic Systems (Fig. 4H, upper panel). When 50\% modified RNA were used, up to eightfold enrichment is achieved compared to unmodified RNA (Fig. 4H, lower panel). We also tested two other $\alpha-\mathrm{m}^{6} \mathrm{~A}$ antibody clones (11D11 and 13G2) and both displayed similar enrichment factors (Supplemental Fig. 2A,B). We next tested $\alpha-m^{5} \mathrm{C} 32 \mathrm{E} 2$ and determined a specific enrichment of more than fourfold, when $1 \%$ of the RNA is modified (Fig. 4l, upper panel). Two commercial antibodies (Diagenode, Cell Signaling) show only mild enrichment. However, when 50\% modified RNA was applied, all three tested antibodies enriched modified RNA (Fig. 4I, lower panel; Supplemental Fig. 2C, D). Finally, we analyzed anti- $\Psi$ clone 27C8 and did not find a specific enrichment of modified versus unmodified RNA in both conditions (Fig. 4J; Supplemental Fig. 2E). This is consistent with the poor performance of the antibody in assays described before and demonstrates that our measurements are specific and reproducible in different approaches. In conclusion, our quantitative data allows for an estimation of antibody performance in solution reminiscent to conditions in genome-wide profiling experiments.

\section{Binding to endogenous modified RNAs}

Modification-specific antibodies are mainly used for RNAprofiling studies. Therefore, it is important to validate binding to endogenous RNAs carrying known modifications. To test this, we investigated whether the tested modification-specific antibodies generally bind to endogenous RNAs by cross-linking them to their RNA targets using UV light irradiation (Fig. 5A). Such an UV cross-linking step is for example crucial in miCLIP experiments (Linder et al. 2015). The anti-m ${ }^{6} \mathrm{~A}$ antibody clone 9B7, the commercial polyclonal antibody (Synaptic Systems), $\mathrm{m}^{5} \mathrm{C}$-specific clone 32E2, the $\mathrm{m}^{5} \mathrm{C}$-specific commercial monoclonal antibody clone 33D3 (Diagenode), the anti- $\Psi$ antibody clone $27 \mathrm{C} 8$ and $\mathrm{m}_{2}{ }^{6} \mathrm{~A}$-specific clone $60 \mathrm{G} 3$ were incubated with total RNA isolated from HEK 293 cells and UV crosslinked. The RNA was partially digested, immunoprecipitates were radioactively labeled at the $5^{\prime}$ end and transferred onto a nitrocellulose membrane (Fig. 5B). Indeed, all antibodies tested except the $\mathrm{m}^{5} \mathrm{C}$-specific antibody clone 33D3 (Diagenode) were efficiently cross-linked and immunoprecipitated, while no signals were observed in non-cross-linked control reactions indicating that the antibodies bind and are efficiently cross-linked to endogenous RNA targets. However, cross-linking efficiencies differ 
A

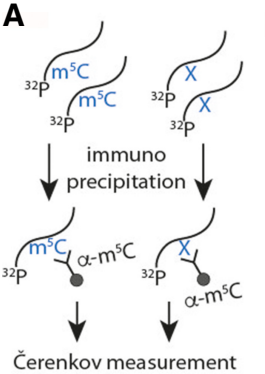

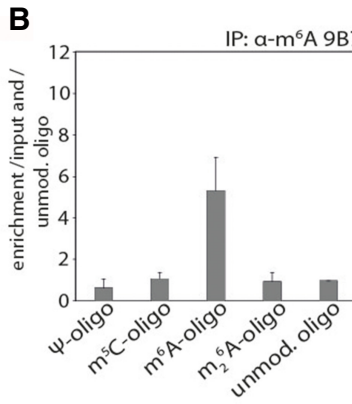

B

E

D
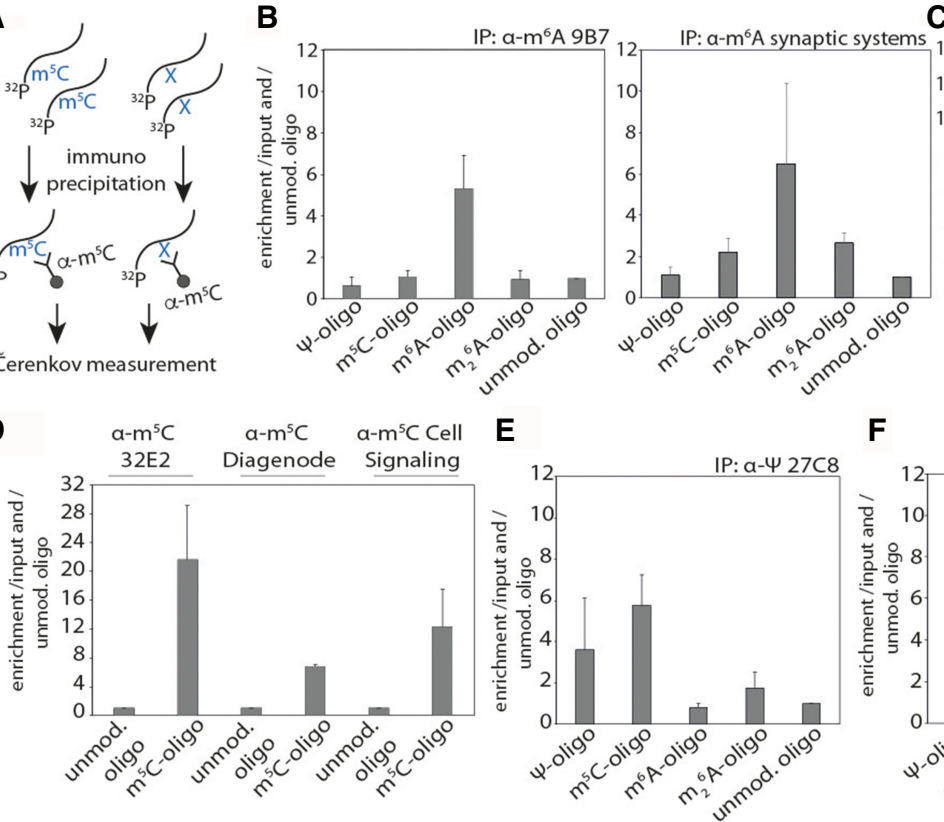

C

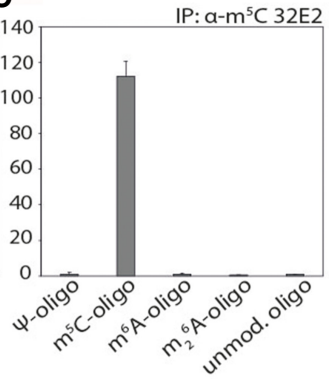

F

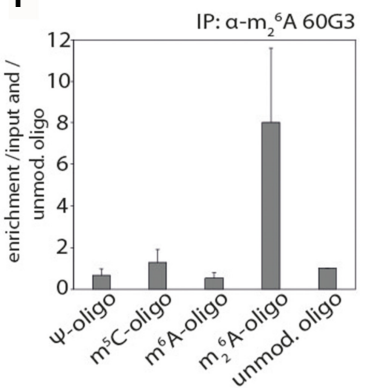

G

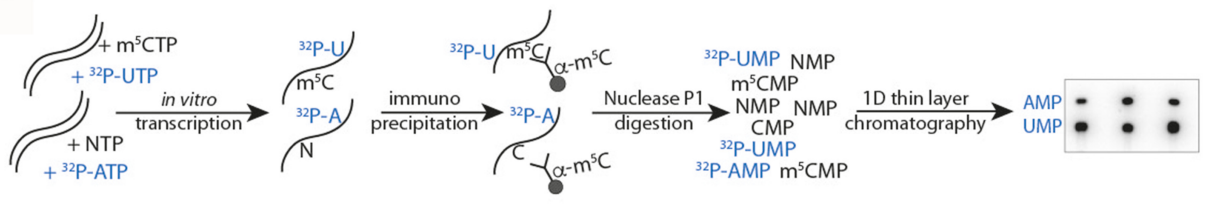

H

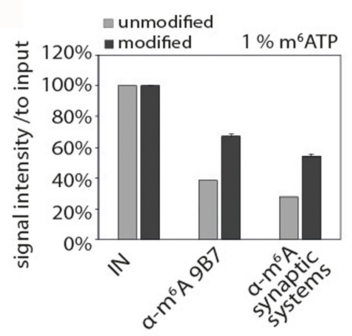

I
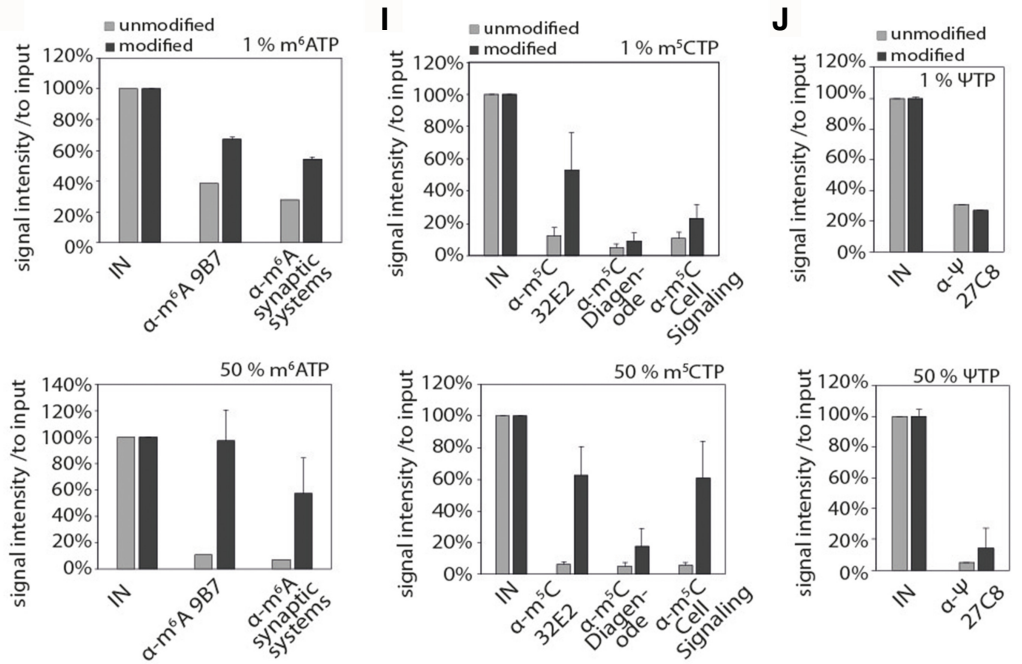

FIGURE 4. Qualitative enrichment of modified vs. nonmodified RNAs using quantitative immunoprecipitation and a thin-layer chromatographybased assay. (A) Schematic overview of the experimental setup. Modified $\left(\mathrm{m}^{5} \mathrm{C}\right.$ as example) and unmodified or differently modified (depicted as $X)$ chemically synthesized oligonucleotides of $12 \mathrm{nt}$ in length were radioactively $5^{\prime}$ labeled. Oligonucleotides were subjected to immunoprecipitation using the indicated antibodies. After washing, the radioactive signals (cpm-values) of the immunoprecipitated RNAs as well as the input samples were measured using a scintillation detector (Cerenkov measurement), and enrichment factors were calculated. (B-F) Depiction of the enrichment of the antibodies $\alpha-m^{6} A$ 9B7, polyclonal $\alpha-m^{6} A$ (Synaptic Systems), $\alpha-m^{5} C$ 32E2, $\alpha-m^{5} \mathrm{C}$ (Diagenode), $\alpha-m^{5} \mathrm{C}(\mathrm{Cell}$ Signaling), $\alpha-\Psi$ $27 \mathrm{C} 8$, and $\alpha-\mathrm{m}_{2}{ }^{6} \mathrm{~A} 60 \mathrm{G} 3$ by using the RNA-IP-based approach, shown in A. (B) Results for the $\mathrm{m}^{6} \mathrm{~A}$ antibodies $9 \mathrm{~B} 7$ and polyclonal Synaptic Systems, $(C)$ the enrichment with antibody $\alpha-m^{5} C 32 E 2,(D)$ enrichment of $\alpha-m^{5} C$ from Diagenode or Cell Signaling, $(E)$ of antibody clone $\Psi$ $27 \mathrm{C} 8$, and $(F)$ depicts the enrichment of the antibody $\alpha-\mathrm{m}_{2}{ }^{6} \mathrm{~A} 60 \mathrm{G} 3$. Experiments were conducted in triplicate. (G) Workflow for enrichment factor using in vitro transcription (ivt), antibody enrichment, and thin layer chromatography (TLC). Ivt with modified ( $\mathrm{m}^{5} \mathrm{CTP}$ as example) and radiolabeled NTPs and immunoprecipitation, the RNA was hydrolyzed with the nuclease P1 and analyzed by TLC. (H) Evaluation of $\mathrm{m}^{6} \mathrm{~A}$ IP-TLC experiments as described above using $1 \%$ (upper panel) or $50 \%$ (lower panel) $\mathrm{m}^{6} \mathrm{ATP}$ for the ivt and analysis of the monoclonal $\mathrm{m}^{6} \mathrm{~A}$ antibody clone $9 \mathrm{~B} 7$ and the polyclonal $\mathrm{m}^{6} \mathrm{~A}$-antibody from Synaptic Systems. The light gray bars show the normalized signal intensities, corresponding to the precipitated unmodified RNA; the dark gray bars show the same for the precipitated modified RNAs. Experiments were conducted in triplicate. (I) Evaluation of $\mathrm{m}^{5} \mathrm{C}$ IP-TLC experiments using $1 \%$ (upper panel) and $50 \%$ (lower panel) $\mathrm{m}^{5} \mathrm{CTP}$ for the ivt and analysis of $\mathrm{m}^{5} \mathrm{C}$ antibody clone 32E2 and commercially available $\mathrm{m}^{5} \mathrm{C}$-specific antibodies from Diagenode and Cell Signaling. Experiments were conducted in triplicate. (J) Determination of the enrichment factors of antibody $\alpha-\Psi 27 \mathrm{C} 8$ based on the RNA-IP and TLC experiments. For these experiments, $1 \%$ (upper panel) and 50\% (lower panel) ITP was used for the ivt. TLCs and further evaluations of other antibodies that we tested can be found in Supplemental Figure 2. 

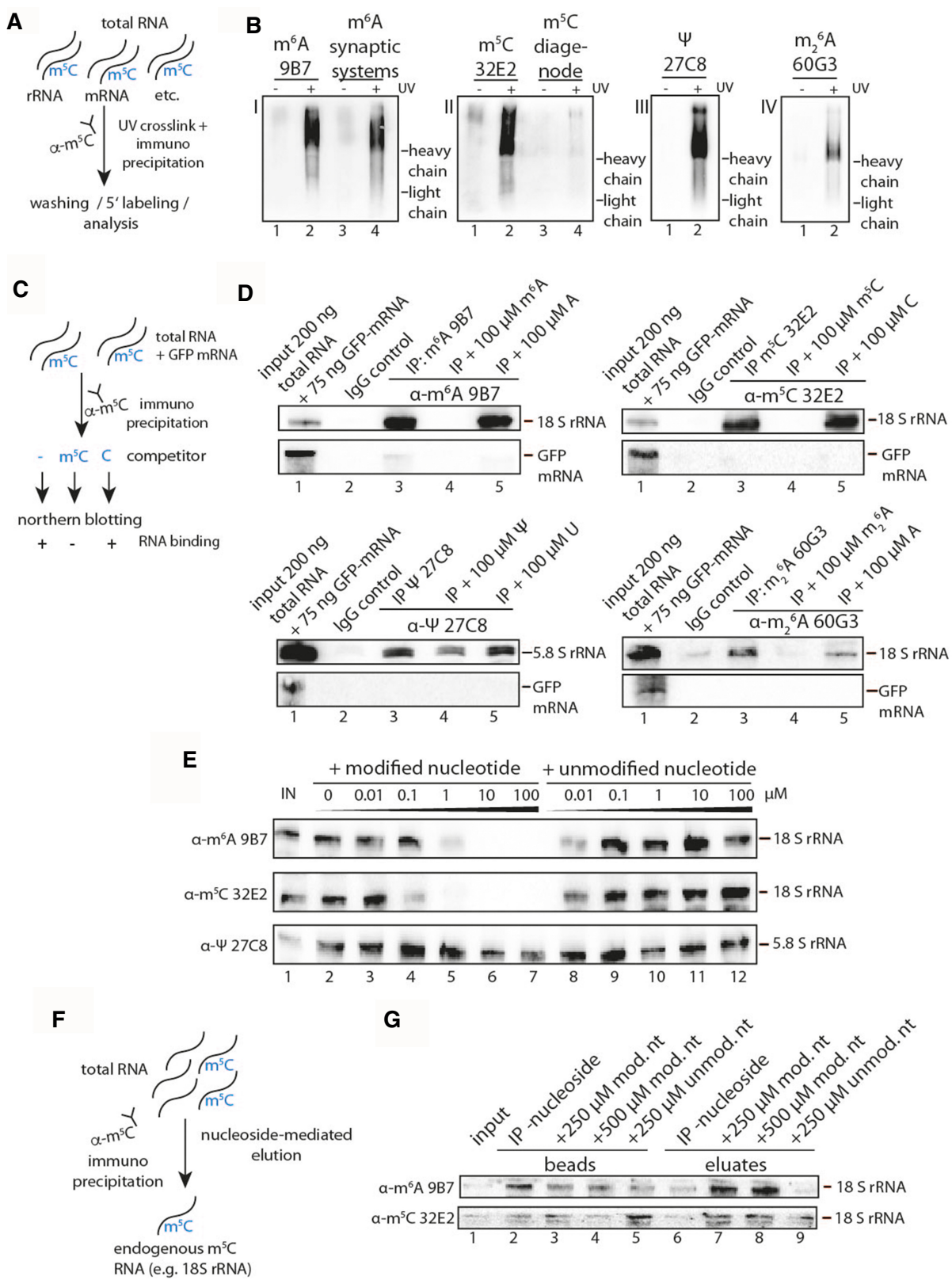

FIGURE 5. Immunoprecipitation of endogenous modified RNAs. (A) Overview of the workflow for cross-linking modification-specific antibodies to endogenous RNAs. Fragmented total RNA from HEK293T cells was cross-linked to the antibody of interest using $254 \mathrm{~nm}$ UV light. RNA was immunoprecipitated, radiolabeled, and the RNA-antibody complexes were analyzed by SDS-PAGE. As a negative control, a nonirradiated setup was used. (B) Autoradiographs of the cross-linking experiments described in A using $\mathrm{m}^{6} \mathrm{~A}$ antibody clones $9 \mathrm{B7}$, Synaptic Systems (I), $\mathrm{m}^{5} \mathrm{C}$ antibody clone 32E2 and the commercial antibody 33D3 (Diagenode) (II), $\alpha-\Psi$ antibody clone 27C8 (III) and $m_{2}{ }^{6} A$ antibody clone $60 G 3$ (IV). (C) Binding competition assays between endogenous RNAs and free nucleosides. Specific antibodies were used for immunoprecipitation from $2 \mu \mathrm{g}$ total HEK293T cell RNA and 75 ng GFP mRNA as a negative control spike-in. To test for specificity, $100 \mu \mathrm{M}$ of the respective modified (e.g., $\mathrm{m}^{5} \mathrm{C}$ ) and unmodified nucleoside (e.g., C) were added to the immunoprecipitation as competitor. The immunoprecipitated RNA was separated on an RNA gel and blotted onto a nylon membrane. A probe against the $18 \mathrm{~S}$ or $5.8 \mathrm{~S}$ rRNA and a probe against the GFP mRNA were used for detection. (D) Northern blots for endogenous $18 \mathrm{~S}$ and $5.8 \mathrm{~S}$ rRNAs as well as GFP mRNA spike-ins. The antibodies $\alpha-\mathrm{m}^{6} \mathrm{~A}$ 9B7, $\alpha-\mathrm{m}^{5} \mathrm{C} 32 \mathrm{E} 2, \alpha-\Psi 27 \mathrm{C} 8$, and $\alpha-m_{2}{ }^{6} A$ 60G3 were used. Input samples (200 ng total RNA and 75 ng GFP mRNA) are shown in lanes 1 and immunoprecipitates using an Ig control antibody used as a negative control in lanes 2. The upper panels show the signals of the 18S/5.8S rRNA; the lower ones for the spiked-in a GFP mRNA. Lanes 3 show signals for untreated IP experiments, lanes 4 depict the signals of an IP competed with modified and lanes 5 with unmodified nucleosides. (E) Competition titration experiment of antibodies $\alpha-m^{6} A 9 B 7, \alpha-m^{5} \mathrm{C} 32 \mathrm{E} 2$, and $\alpha-\Psi 27 \mathrm{C} 8$. Different concentrations ranging from 10 to $100 \mu \mathrm{M}$ of modified and unmodified nucleosides were added to RNA-IP experiments. For detection, probes against 18S and 5.8S rRNA were used. (F) Nucleoside-mediated elution of antibody-bound endogenous 18S rRNA. (G) Northern blots of immunoprecipitation experiments using antibodies $\alpha-m^{6} \mathrm{~A} 9 \mathrm{~B} 7$ and $\alpha-\mathrm{m}^{5} \mathrm{C} 32 \mathrm{E} 2$. RNA either extracted from beads (lanes $2-5$ ) or from specifically eluted supernatants (lanes 6-9) were analyzed by northern blotting. Lane 1 shows the input of the immunoprecipitation experiments. 
between the antibodies possibly reflecting different modification levels or antibody affinities.

All four modifications, against which antibodies were established, are present in rRNA (Cecchini and Miassod 1979). Thus, we next asked whether these antibodies also specifically immunoprecipitate rRNA. Antibodies were coupled to beads and incubated with total RNA isolated from HeLa cells (Fig. 5C). For specificity control, in vitro transcribed GFP mRNA was added to the mixture. After washing, the immunoprecipitated RNA was analyzed by northern blotting using probes against $18 \mathrm{~S}$ and $5.8 \mathrm{~S}$ rRNA, respectively. Antibodies $\alpha-m^{6} \mathrm{~A} 9 \mathrm{~B} 7, \alpha-\mathrm{m}^{5} \mathrm{C}$ 32E2, and $\alpha-m_{2}{ }^{6} A$ 60G3 efficiently immunoprecipitated $18 \mathrm{~S}$ rRNA, while $\alpha-\Psi$ 27C8 enriched 5.8S rRNA albeit less efficient (Fig. 5D, lanes 3 of each panel). lgG subtype-specific control antibodies confirmed the specificity of the analyzed antibodies (Fig. 5D, lanes 2). These data highlight that endogenous target RNAs are bound by the tested antibodies and thus might be suitable for profiling experiments.

Since we found that the anti- $\mathrm{m}^{6} \mathrm{~A}$ antibodies $9 \mathrm{~B} 7$ and $19 B 7$ were efficiently cross-linked to endogenous RNAs by UV irradiation (Fig. 5A,B), we performed miCLIP assays to determine $\mathrm{m}^{6} \mathrm{~A}$ modification of endogenous mRNA. We defined a gene set of 17,158 peaks from MEF cells, which harbored at least one peak in each of the three replicates when performing miCLIP experiments with a commercial antibody (Abcam) (Supplemental Fig. 3B). These genes represented $65.6 \%, 75.5 \%$, or $69.1 \%$ of the peaks in the three different replicates, indicating high reproducibility. We then analyzed whether our antibodies also pulleddown $\mathrm{m}^{6} \mathrm{~A}$ targets enriched by the Abcam antibody. Performing miCLIP with either 9B7 or 19B7 antibodies revealed a similar distribution of peaks over individual mRNAs like Cdk9 as the commercial antibody and displayed a typical enrichment of signals in the $3^{\prime}$ UTR. In addition, $\mathrm{C}$ to $\mathrm{T}$ transition mutations occurred on the $\mathrm{m}^{6} \mathrm{~A}$ DRACH motif on mRNAs like Slc2a1 for all three antibodies tested (Supplemental Fig. 3C,D). Moreover, about 5671 peaks were similarly identified by both of our newly generated anti-m ${ }^{6} \mathrm{~A}$ antibodies, and this overlap represented $32.7 \%$ or $25.9 \%$ of peaks with one $\mathrm{m}^{6} \mathrm{~A}$ peak in the samples generated with 9B7 or 19B7 antibodies (Supplemental Fig. 3C). Collectively, these data indicate that the monoclonal antibodies can be used for CLIP experiments to determine the targets and positions of $\mathrm{m}^{6} \mathrm{~A}$ modifications.

\section{Competition and elution experiments using modified and unmodified nucleosides}

To further test for antibody specificity, competition experiments with the respective epitopes were performed. For $\alpha-m^{6} \mathrm{~A} 9 \mathrm{~B} 7, \alpha-\mathrm{m}^{5} \mathrm{C} 32 \mathrm{E} 2$, and $\alpha-\mathrm{m}_{2}{ }^{6} \mathrm{~A} 60 \mathrm{G} 3$, the modified nucleotide efficiently competed with $18 \mathrm{~S}$ rRNA binding (Fig. 5D, lanes 4). Competition with $\Psi$, however, inhibited binding of $\alpha-\Psi 27 \mathrm{C} 8$ to $5.8 \mathrm{~S}$ rRNA rather weakly (Fig. 5D).
The unmodified nucleotides did not show any competition with $\alpha-m^{6} \mathrm{~A} 9 \mathrm{~B} 7, \alpha-\mathrm{m}^{5} \mathrm{C} 32 \mathrm{E} 2$, and $\alpha-\Psi 27 \mathrm{C} 8$. For $\alpha-\mathrm{m}_{2}{ }^{6} \mathrm{~A}$ $60 \mathrm{G} 3$, a mild reduction of $18 \mathrm{~S}$ rRNA binding was observed when the unmodified nucleotide was added (Fig. 5D). Thus, these data suggest that except for $\alpha-\Psi 27 C 8$, antibodies $\alpha-m^{6} A$ 9B7, $\alpha-m^{5} \mathrm{C} 32 \mathrm{E} 2$, and $\alpha-m_{2}{ }^{6} \mathrm{~A} 60 \mathrm{G} 3$ bind their modified nucleotide targets specifically. Lower affinity and specificity of $\alpha-\Psi 27 C 8$ is consistent with our previous results. To receive a more comprehensive picture of nucleotide competition and to assess optimal conditions for nucleoside-mediated elution, we performed titration experiments using nucleotide concentrations ranging from $10 \mathrm{nM}$ to $100 \mu \mathrm{M}$ and performed experiments as described above (Fig. 5E). Consistently, 18S rRNA binding was strongly reduced when a concentration of $1 \mu \mathrm{M}$ modified nucleotide was added to the washing buffer. As expected, unmodified nucleotides did not inhibit binding (Fig. 5E). As observed in the experiments before, competition using $\alpha-\Psi 27 C 8$ was less efficient and binding to the 18S rRNA was not completely lost even when 100 $\mu \mathrm{M}$ nucleotide concentrations are used (Fig. 5E).

To increase specificity in immunoprecipitation experiments, bound factors can be eluted by an excess of the antigen. To test whether this strategy is applicable to modification-specific antibodies as well, we immunoprecipitated the 18S rRNA from total RNA samples using $\alpha-m^{6} \mathrm{~A} 9 \mathrm{~B} 7$ and $\alpha-\mathrm{m}^{5} \mathrm{C}$ 32E2 (Fig. 5F,G). We incubated the immunoprecipitation reactions with 250 and $500 \mu \mathrm{M}$ modified nucleosides and analyzed the eluates by northern blotting. Indeed, an excess of both, $\mathrm{m}^{6} \mathrm{~A}$ and $\mathrm{m}^{5} \mathrm{C}$ efficiently eluted the $18 \mathrm{~S}$ rRNA from affinity beads, while the unmodified nucleosides had a much weaker or no effect (Fig. 5G, lanes 5, 9). Taken together, binding of $\alpha-m^{6} A$ 9B7 and $\alpha-m^{5} \mathrm{C} 32 \mathrm{E} 2$ antibodies to $18 \mathrm{~S}$ rRNA is efficiently competed by the respective modified nucleosides and bound RNAs can be efficiently eluted.

\section{Detection of modified nucleic acids by immunofluorescence}

Antibodies are widely used for the visualization of intracellular localization patterns of their antigens. Therefore, we tested whether modification-specific antibodies are useful for immunofluorescence applications as well (Fig. 6). In order to assess signal specificity for anti-m ${ }^{6} \mathrm{~A}$ antibodies, we knocked out METTL3, the enzyme that generates $\mathrm{m}^{6} \mathrm{~A}$ on mRNAs, from C643 cells and compared the signals and wild-type (wt) cells. METTL3 knock out was confirmed by western blotting (Fig. 6A). As expected, full digestion of poly(A)-selected RNAs from these cells and subsequent identification of $\mathrm{m}^{6} \mathrm{~A}$ nucleotides by HPLC analysis shows strong $\mathrm{m}^{6} \mathrm{~A}$ reduction in METTL3 knock out cells (Fig. 6B, C). The remaining signal most likely originates from rRNA contaminations. Of note, a less abundant shorter band is detected on western blots, which could be a truncated 
A

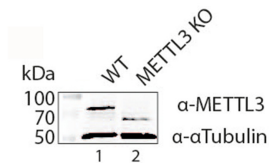

D
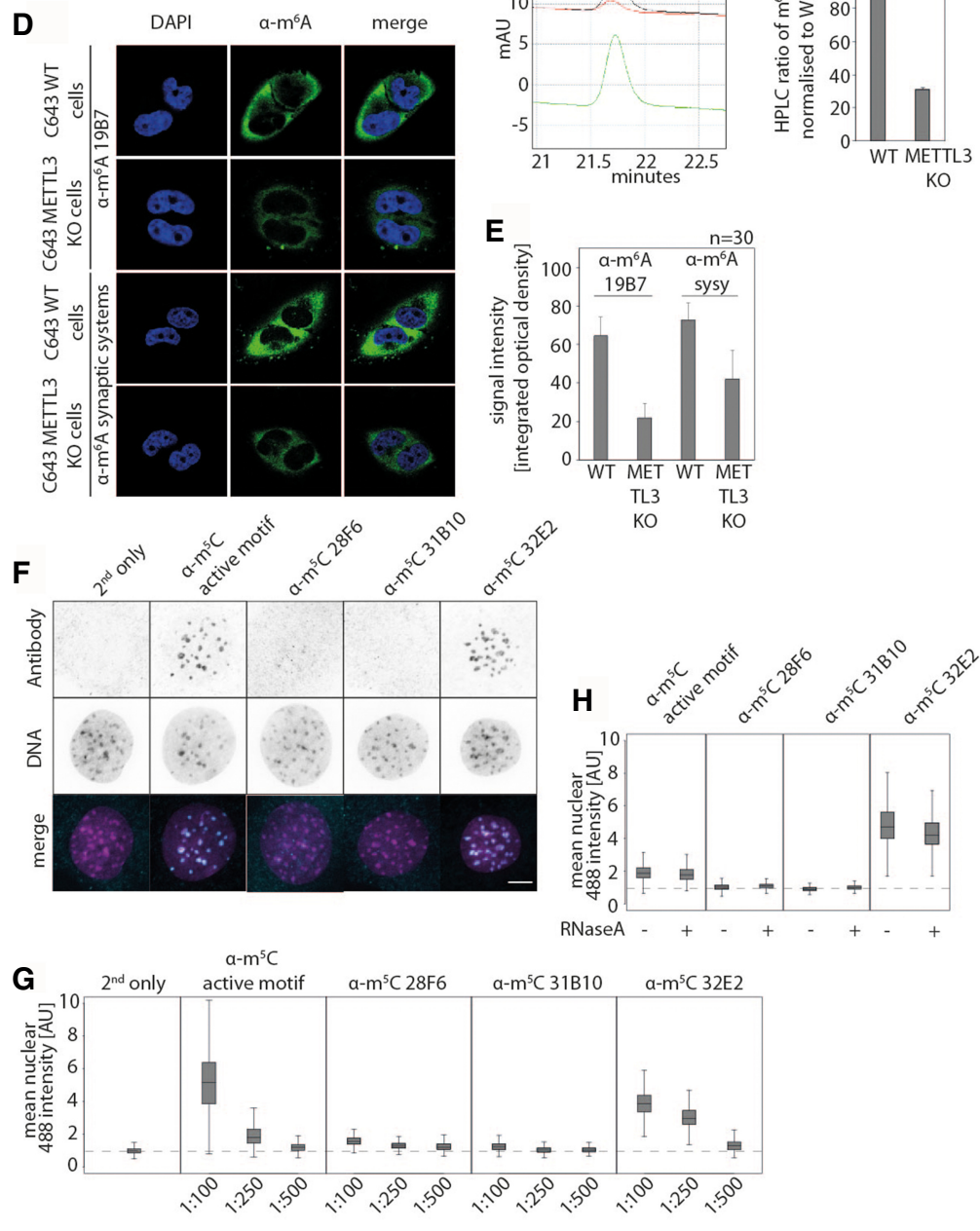

FIGURE 6. Immunofluorescence stainings of C643 wild-type (WT) and METTL3 knockout (KO) cell lines using $\alpha-m^{6} A$ antibodies and immunofluorescences of MTF cells stained with $\alpha-m^{5} C$ clone 32E2 detecting genomic $\mathrm{m}^{5} \mathrm{C}$. (A) Western blot analysis of C643 WT and METTL3 KO cell lysates, probed with antibodies against METTL3 and $\alpha$-Tubulin as a loading control. (B) Verification of $\mathrm{m}^{6} \mathrm{~A}$ levels in the mRNA of C643 cells of WT compared to METTL3 KO by HPLC measurements. $(C)$ Integrated values from $B$ were normalized to WT and are given in percentages. (D) Immunofluorescences of WT and METTL3 KO cells. The cells were stained with $\alpha-m^{6} A 19 B 7$ (upper part) and polyclonal $\alpha-m^{6} A$ Synaptic Systems (lower part). The DAPI staining (blue) shows the nuclei of the cells; in green, the $\mathrm{m}^{6} \mathrm{~A}$ signals are shown. The right panel displays merged stainings. (E) Quantification of the signal intensities of the immunofluorescence staining of WT and METTL3 KO cells shown in A. For quantification, 30 cells each were analyzed. $(F)$ Exemplary pseudo-colored maximum confocal Z-projections of RNaseA treated mouse tail fibroblasts (MTFs), stained with the indicated $\mathrm{m}^{5} \mathrm{C}$ antibodies diluted 1:250. An Alexa Fluor 488 conjugated secondary antibody was used to visualize the primary antibodies. DNA was stained with DAPI (scale bar, $10 \mu \mathrm{m}$ ). (G) Boxplots showing the normalized mean nuclear Alexa Fluor 488 intensities. Nuclear levels were normalized against cells stained without any primary antibody ("second only"). The outcome of three tested antibody dilutions, 1:100, 1:250, 1:500, is shown $(n>15,000)$. The dashed line indicates the median of "second only" cells. $(H)$ Boxplots showing the normalized mean nuclear levels of Alexa Fluor 488 in MTF cells treated with or without RNaseA and stained with an antibody dilution of 1:250 ( $n>40,000)$. Signal levels of Alexa Fluor 488 were normalized against control cells that were only stained with the secondary antibody. The dashed line indicates the median of cells, stained without primary antibody.
METTL3 (Fig. 6A). However, since $m^{6} A$ levels are strongly reduced, we assume that such a putative truncated version is most likely nonfunctional. We next performed confocal microscopy-based immunofluorescence studies using the anti- ${ }^{6} \mathrm{~A}$ clones as well as the commercial anti$\mathrm{m}^{6} \mathrm{~A}$ antibody (Synaptic Systems) for comparison (Fig. 6D, clone 19B7 is shown as example). Both antibodies strongly stained the cytoplasm of wt C643 cells while nuclear signals were not detected. METTL3 knock out C643 cells, however, show a markedly reduced cytoplasmic signal suggesting that both antibodies recognize $\mathrm{m}^{6} \mathrm{~A}$-modified RNAs in immunofluorescence experiments. Noncoding RNAs such as rRNAs or snRNAs contain $\mathrm{m}^{6} \mathrm{~A}$ modifications but these modifications are independent of METTL3 function and thus the signal was only reduced by $\sim 40 \%$ as revealed by signal intensity measurements (Fig. 6E). Using an alternative staining protocol optimized for staining chromatin-associated factors and modifications, the $\mathrm{m}^{6} \mathrm{~A}$ clone 19B7 showed a specific cytoplasmic staining, while other clones did not show specific signals (Supplemental Fig. 4A-C).

$M^{5} \mathrm{C}$ is a very abundant modification on DNA and it is often found at promoter regions. It is enriched in distinct areas referred to as CpG islands and associated with epigenetic gene regulation processes (Jones 2012). We therefore tested whether $\alpha-m^{5} \mathrm{C}$ antibodies also recognize modified DNA in immunofluorescence stainings (Fig. 6F-H). Mouse-tail fibroblasts were permeabilized, treated with RNase A to test DNA specificity and stained with $\mathrm{m}^{5} \mathrm{C}$-specific antibodies (Fig. 6F; Ludwig et al. 2017). Both, the widely used commercial monoclonal antibody 33D3 (Active Motif) and our clone 32E2 detected distinct nuclear foci, which colocalized with DAPI-dense DNA structures (Fig. 6F, middle and lower panels). These supra-chromosomal structures are termed chromocenters and correspond to clusters of constitutive 
pericentromeric heterochromatin that are composed by tandem repeats of $\mathrm{m}^{5} \mathrm{C}$ enriched major satellite DNA (Casas-Delucchi et al. 2012). These data indicate that both clones recognize $\mathrm{m}^{5} \mathrm{C}$-modified DNA in immunostaining experiments. The clones $\alpha-m^{5} \mathrm{C} 28 \mathrm{~F} 6$ and 31B10, however, did not show specific signals suggesting that these antibodies are RNA-specific or not sensitive enough to allow the detection of modified DNA in immunofluorescence studies. We further tested different antibody dilutions and quantified the nuclear signal relative to the negative control (Fig. 6G, dashed line, "second only": secondary antibody only). The signal is lost when the antibody is linearly diluted suggesting an ideal dilution of 1:100 in such assays. Propidium iodide treatment, which stains not only DNA but also RNA showed a moderate reduction of the nuclear signal when RNase A treatment was performed. The mild reduction shows that a small portion of the nuclear nucleic acid is indeed RNA (Supplemental Fig. 4D). We next compared RNase A-treated with nontreated cells (Fig. 6H). A dilution of 1:250 was chosen to avoid unspecific signals due to high antibody concentrations. Consistently with our previous results, RNase $A$ treatment does not affect nuclear staining indicating that the two $\alpha-m^{5} \mathrm{C}$ clones 33D3 (Active Motif) and 32E2 (this work) are DNA-specific under these experimental conditions. Since at least clone
32E2 detects efficiently modified RNA molecules, our results suggest that $\mathrm{m}^{5} \mathrm{C}$-modified RNAs are mainly found in the cytoplasm of these cells.

Taken together, modification-specific antibodies can be used for immunofluorescence as well, as exemplified by a number of antibodies that we tested.

\section{$m^{6} A$ detection in cell sorting experiments}

In previous experiments, we have provided methods to validate antibody performance in solution und thus we asked whether we could also use such antibodies for fluorescence-activated cell sorting (FACS) experiments. As an example, we used $\mathrm{m}^{6} \mathrm{~A}$-specific antibodies since knock out cell lines of the writer machinery are available and can be used for comparison (Fig. 7). Flow cytometry analysis of wt mouse embryonic fibroblasts (MEFs) revealed that $m^{6} A$-modified RNA was robustly detected using anti$\mathrm{m}^{6} \mathrm{~A}$ antibody clones 9B7, 11D11 and 19B7, as they also determined decreased $\mathrm{m}^{6} \mathrm{~A}$ abundance in Wtap-deficient MEF cells (Fig. 7A, red overlay). Wtap is an essential component of the $\mathrm{m}^{6} \mathrm{~A}$ writer complex and its expression was indeed lost in knockout cells as assessed by FACS with anti-Wtap antibodies (Fig. 7B, red overlay). Of note, a commercially available antibody (Abcam) did not distinguish

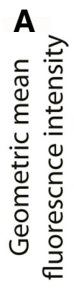
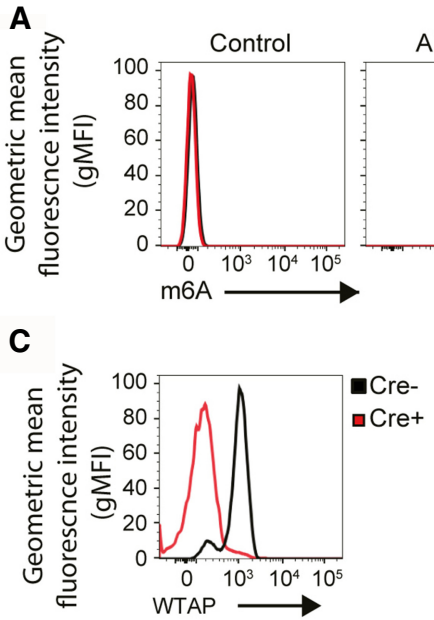

Abcam

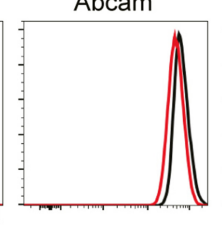

D

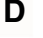

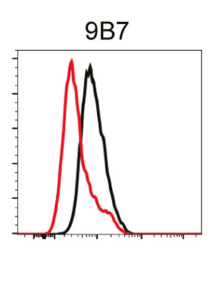

9B7

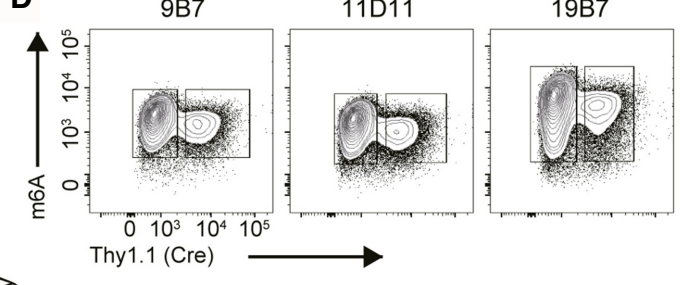

E

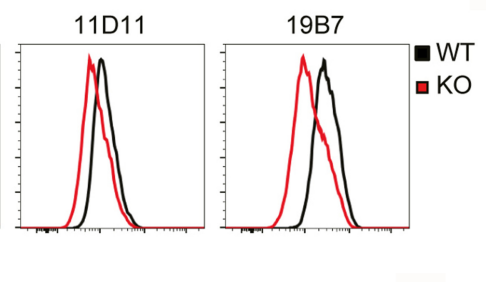

B

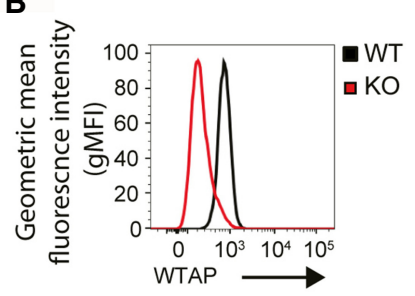

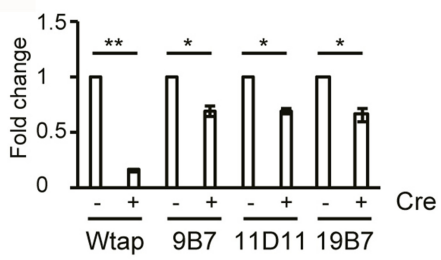

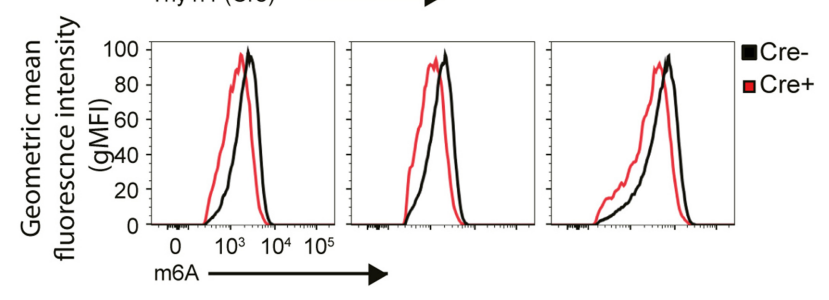

FIGURE 7. (A) Flow cytometry comparison of MEF cells stained with purified anti-m ${ }^{6} \mathrm{~A}$-specific rat monoclonal antibodies or polyclonal commercial anti-m ${ }^{6} \mathrm{~A}$ antibodies (Abcam). Staining with a secondary anti-rat antibody served as a negative control. Data are representative of three independent experiments. $(B, C)$ Deletion of Wtap in Wtap ${ }^{-1-}$ MEF cells after puromycin selection $(B)$ or acute deletion via Cre transduction of MEF cells at Day $4(C)$ was confirmed via anti-Wtap staining. $(D, E)$ Flow cytometry analysis of $\mathrm{m}^{6} \mathrm{~A}$ and Thy1.1 (Cre) in Cre-transduced MEF cells Day 7 is shown as contour plot $\left(D\right.$, upper panel) indicating the gates used to overlay $m^{6} A$ levels that are present in the Thy 1.1 positive $(D$, lower panel, red) and Thy1.1 negative ( $D$, lower panel, black) cells. (E) The fold change of the geometric mean fluorescence intensity (gMFI) of Wtap (C) or $\mathrm{m}^{6} \mathrm{~A}(\mathrm{D}$, lower panel) is shown. 
between wt and WTAP knock out cells. To rule out clonal variation that may arise during drug-selection of MEF cell lines, we investigated whether these antibodies also specifically recognized $\mathrm{m}^{6} \mathrm{~A}$-modified RNAs after acute depletion of Wtap. As shown in Figure 7C, the expression of Wtap was drastically reduced after retroviral transduction expressing the Cre recombinase, marked by coexpression of Thy1.1 in Wtapflox/flox MEF cells (Fig. 7C). Consistently, all monoclonal antibodies recognized the difference of $\mathrm{m}^{6} \mathrm{~A}$ levels between Thy1.1+ (i.e., Cre-expressing, Wtap-deficient cells) and the Thy1.1- (WT cells) (Fig. 7D,E). In summary, base modification-specific antibodies can in general be used for FACS experiments.

\section{DISCUSSION}

Base-specific antibodies are widely used for the detection of modified RNAs and have been vital for the tremendous progress made in the analysis of $\mathrm{m}^{6} \mathrm{~A}$ functions. The success of $\mathrm{m}^{6} \mathrm{~A}$-specific antibodies fostered the development of antibodies against other modifications. However, such modifications appear to be much less abundant on mRNAs and the used antibodies are often only partially validated. Therefore, not always reliable and sometimes even conflicting results were produced. These developments contributed to the view that antibody-based profiling of RNA modifications might be generally error-prone (Helm et al. 2019). Moreover, antibody-independent approaches have been developed for individual modifications and these methods also produced distinct results. For example, bisulfite-sequencing approaches were performed for $\mathrm{m}^{5} \mathrm{C}$ modifications and led to very different results with mRNA targets ranging from very few to thousands (Squires et al. 2012; Edelheit et al. 2013; Hussain et al. 2013; Amort et al. 2017; Legrand et al. 2017; Huang et al. 2019). In addition, bulky chemical adducts are linked to specific modifications acting as roadblocks in PCR reactions and thus defining the position of the modification. For example, CMC-addition to $\Psi$ has been developed but highly varying data sets were reported (Zaringhalam and Papavasiliou 2016; Zhou et al. 2018). To validate these results, independent methods are required and therefore we set out to provide example strategies and methods for characterizing modification-specific antibodies. We established monoclonal antibodies that specifically bind $m^{6} A, m_{2}^{6} A, m^{5} C$, and $\Psi$ modifications to obtain larger amounts of antibodies for testing since commercial antibodies are rather cost-intensive and could therefore not be included in all experiments.

A main shortcoming of available antibodies is that affinities and enrichment factors are often unknown. We therefore developed a method to define these key numbers. We found that all antibody clones, except antibodies against $\Psi$, bound free nucleosides in the low $\mu \mathrm{M}$ range (Fig. 2G). However, it is important to note that these num- bers might differ in the context of longer RNA molecules. Since the antibodies discriminate between modified and unmodified bases, it is likely that bases will also be efficiently bound when embedded into larger RNAs but affinities might differ. Another informative number for estimating antibody performance is the enrichment factor indicating "fold enrichment" of modified over unmodified RNAs (Fig. 4). In two different assays, we found that a commercially available antibody directed against $\mathrm{m}^{6} \mathrm{~A}$ (Synaptic Systems) as well as antibody clones developed in our laboratory enrich modified RNAs between 1.5and sixfold. Our $\mathrm{m}^{5} \mathrm{C}$-specific antibody enriched RNA fourfold in a TLC-based assay (Fig. 4I) and more than 100-fold in an independent RNA-IP-based approach with chemically synthesized RNA oligonucleotides (Fig. 4D). Of note, commercial antibodies enriched $\mathrm{m}^{5} \mathrm{C}$-modified RNA only marginally. These and other antibodies were mainly generated to detected $\mathrm{m}^{5} \mathrm{C}$ in DNA. Thus, they may detect additional structural aspects of double stranded DNA, which are not present in short single-stranded RNA fragments. Nevertheless, the $\alpha-m^{5} \mathrm{C}$ antibody clone 32E2 also recognized DNA in immunofluorescence staining experiments (Fig. 6F) while the other established $\alpha-m^{5} \mathrm{C}$ antibody clones did not stain DNA foci. In summary, for obtaining solid and reproducible results, it is important that affinities and efficiencies are considered when antibodies are combined with RNA-seq approaches.

Immunofluorescence staining with $\mathrm{m}^{6} \mathrm{~A}$ antibodies detected $m^{6} A$ RNAs in the cytoplasm and the signal was reduced in METTL3 knock out cells (Fig. 6A-E). Since $m^{6} A$ modifications on noncoding RNAs such as rRNAs or snRNAs are independent of METTL3, such a pattern is expected. However, it was unexpected that no nuclear signal was detected (Fig. 6D) because the nuclear U6 snRNA, for example, carries one $\mathrm{m}^{6} \mathrm{~A}$ modification (Bohnsack and Sloan 2018). Furthermore, several YTH domain reader proteins are localized to the nucleus suggesting nuclear $\mathrm{m}^{6} \mathrm{~A}$-modified RNAs are also present in this cellular compartment. Several scenarios explaining the lack of nuclear $m^{6} A$ signals can be envisioned. First, the YTH domain covers the $m^{6} \mathrm{~A}$ base and thus the epitope is not accessible for antibodies. Second, nuclear RNAs containing $m^{6} \mathrm{~A}$ modifications are rather unstable and therefore of low abundance and not visible since $\mathrm{m}^{6} \mathrm{~A}$ might tag for rapid degradation. Third, the modified U6 snRNA could be deeply buried into the spliceosome and again the single modified base might not be accessible for antibodies. It is further conceivable that these aspects are also relevant for the cytoplasmic signal and the actual level of modified RNA in the cytoplasm might be even higher.

In summary, we generated and thoroughly validated a number of monoclonal antibodies. The antibody clones $9 B 7\left(m^{6} A\right), 32 E 2\left(m^{5} \mathrm{C}\right)$, and 60G3 $\left(m_{2}^{6} A\right)$ are suitable for various applications such as RIP, immunofluorescence approaches, CLIP and FACS. However, we also emphasize 
that each individual base-specific antibody needs to be optimized regarding the experimental conditions and it is difficult to generalize such conditions in a single protocol. Concentration, dilution, salt conditions are very important and each antibody has to be optimized for the individual experimental settings. We strongly recommend that antibody conditions and performance in a number of different assays as exemplified here, should be assessed prior to usage and this should become a prerequisite rather than an option for publication.

\section{MATERIALS AND METHODS}

\section{Coupling of the nucleosides to ovalbumin}

The coupling protocol of nucleosides to ovalbumin is based on the method described by (Erlanger and Beiser 1964). An amount

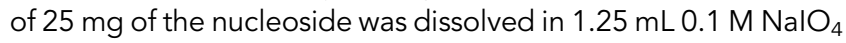
and incubated for $20 \mathrm{~min}$ at room temperature. An amount of $75 \mu \mathrm{L} 1 \mathrm{M}$ ethylene glycol was added and incubated for another $5 \mathrm{~min}$ at room temperature. An amount of $50 \mathrm{mg}$ of ovalbumin was dissolved in $5 \mathrm{~mL} \mathrm{H}_{2} \mathrm{O}$. The $\mathrm{pH}$ was adjusted to 9 using a $5 \% \mathrm{~K}_{2} \mathrm{CO}_{3}$ solution. After adding the oxidized nucleoside to the ovalbumin solution, the mixture was stirred for 45 min, keeping the $\mathrm{pH}$ constantly at 9. A freshly prepared reduction solution (75 mg NaBH $4 / 5 \mathrm{~mL} \mathrm{H}_{2} \mathrm{O}$ ) was then added to the conjugate and incubated overnight at room temperature. Using $1 \mathrm{M}$ formic acid, the $\mathrm{pH}$ was reduced to 5-6 and incubated for another hour at room temperature. After adjusting the $\mathrm{pH}$ to 8.5 using $1 \mathrm{M} \mathrm{NH}_{3}$, the solution was gel filtrated on a Superose 12 column (GE Healthcare) in $0.2 \mathrm{M}$ ammonium formate, $\mathrm{pH}$ 8.5. For analysis, the absorption of a defined amount of the conjugate was measured via UV spectroscopy. The molar ratio of bound nucleoside per carrier protein was estimated by measuring the absorbance of the conjugate at 5 different wavelengths $(250,260,270,280$, and $290 \mathrm{~nm}$ ) and fitting the measured data to the corresponding calculated absorption values. The spectrum of the conjugate was assumed to be the sum of nucleoside and carrier protein spectra. The absorbance was calculated by the extinction coefficients at the different wavelengths and the composition of the constituents. To obtain the "best fit"-composition of nucleoside and carrier protein, a grid search with a resolution of $0.1 \mu \mathrm{g}$ was conducted using the sum-of-squares of the differences between measured and calculated absorption values as fit indicator.

\section{Generation of monoclonal antibodies recognizing $m^{5} \mathrm{C}, \mathrm{m}^{6} \mathrm{~A}$, and pseudouridine $(\psi)$ and ELISA screening}

Approximately $50 \mu \mathrm{g}$ of modified nucleobases coupled to ovalbumin (OVA) were dissolved in PBS, emulsified in an equal volume of incomplete Freund's adjuvant (Sigma) supplemented with $5 \mathrm{nmol}$ CpG oligonucleotides (TIB Molbiol, Berlin), and injected both intraperitoneally (i.p.) and subcutaneously (s.c.) into Wistar rats and C57BL/6N mice. After 6 to $8 \mathrm{wk}$, a boost with $50 \mu \mathrm{g}$ of nucleobase-conjugated OVA without Freund's adjuvant was given $3 \mathrm{~d}$ before fusion. Fusion of the myeloma cell line P3X63-Ag8.653 with splenic $B$ cells of immunized rat or mouse was performed ac- cording to standard procedures (Kohler and Milstein 1975). P3X63-Ag8.653 cells were cultured at $37^{\circ} \mathrm{C}$ in a humidified $5 \%$ $\mathrm{CO}_{2}$ incubator in standard medium RPMI 1640 (Sigma/GIBCO), supplemented with $1 \%$ glutamine, $1 \%$ nonessential amino acids, $1 \%$ sodium pyruvate, $1 \%$ penicillin/streptomycin (Sigma), and $2.5 \%$ FCS (PAN). Hybridoma cells were cultured in standard RPMI 1640 medium supplemented with 20\% FCS and 2\% HT supplement (Life Technologies). Hybridoma supernatants were positively tested in a solid-phase enzyme-linked immunoassay (ELISA) using the corresponding modified nucleobase coupled to BSA and negatively tested on nonmodified nucleobase also coupled to BSA. To identify $\mathrm{m}^{6} \mathrm{~A}$-specific hybridoma clones, 96-well polystyrene plates were coated with $\mathrm{m}^{6} \mathrm{~A}$-conjugated BSA overnight at room temperature ( $\left.{ }^{6} \mathrm{~A}-\mathrm{BSA}: 2.5 \mu \mathrm{g} / \mathrm{mL}\right)$. In parallel, 96-well plates were coated with $\mathrm{m}_{2}{ }^{6} \mathrm{~A}$ and $\mathrm{A}$ (conc.: $2.5 \mu \mathrm{g} /$ $\mathrm{mL}$ ). To identify $\mathrm{m}^{5} \mathrm{C}$-specific antibodies, screening plates were coated with $\mathrm{m}^{5} \mathrm{C}$ (positive screen) and $\mathrm{C}$ (negative screen), for screening plates were coated with $\Psi$ (positive screen) or $C$ and $U$ (negative screens). After coating, plates were washed once with PBS, unbound sites were blocked with $2 \%$ FCS in PBS for 20 min. After washing off unbound nucleobase BSA-conjugates, hybridoma supernatants (1:10 diluted) were added and incubated for $30 \mathrm{~min}$. After another wash with PBS, plates were incubated for 30 min with a mix of HRP-coupled subclass-specific mouse anti-rat or rat anti-mouse secondary antibodies. After five washes with PBS, TMB substrate (1 Step Ultra TMB-ELISA; ThermoFisher Scientific Inc.) was added and the absorbance was measured at $650 \mathrm{~nm}$ with a microplate reader (Tecan). To determine the specific antibody subclasses in a second validation after expansion of positive clones, respective BSA-nucleobase conjugates were coated onto 96-well polystyrene plates as described above, incubated with the hybridoma supernatants and then detected with HRP-coupled monoclonal mouse or rat antibodies specific for the different lgG subclasses of rat or mouse, respectively. Selected hybridoma cells of positively tested supernatants specific for $m^{6} A$ (13G2 rat lgG2a, 11D11 rat lgG1, 9B7 rat lgG1), $m^{5} \mathrm{C}$ (31B10 mouse IgG1/ $\lambda$, 28F6 mouse lgG2b, 23E2 mouse $\operatorname{lgG} 2 \mathrm{c} / \lambda), \mathrm{m}_{2}{ }^{6} \mathrm{~A}$ (60G3 rat lgG2a), and $\Psi$ (26H5 mouse igG2b, $27 \mathrm{C} 8$ mouse lgG2b) were cloned at least twice by limiting dilution.

\section{Capture ELISA}

Subclass-specific antibodies were coated onto microplates (200 $\mathrm{mM} \mathrm{Na}{ }_{2} \mathrm{CO}_{2} \mathrm{pH} 9.5,12 \mathrm{~h}$, at $4^{\circ} \mathrm{C}$ ). The following concentrations of subclass-specific antibodies were used: mouse $\operatorname{lgG} 1$ and IgG2a: $3 \mu \mathrm{g} / \mathrm{mL}$; mouse $\lg 2 \mathrm{~b}$ and rat $\operatorname{lgG} 1: 5 \mu \mathrm{g} / \mathrm{mL}$; rat lgG2a: $20 \mu \mathrm{g} / \mathrm{mL}$. The plates were blocked with $2 \%$ FCS in PBS. Hybridoma supernatants were incubated for $30 \mathrm{~min}$ at room temperature. After washing with PBS, the respective OVA-conjugated modified nucleotide was added at a concentration of $2.5 \mu \mathrm{g} / \mathrm{mL}$ and incubated for $30 \mathrm{~min}$ at room temperature. After incubation with a HRP-conjugated polyclonal ovalbumin-specific antibody and several PBS washes, TMB substrate was added and absorbance was detected with a microplate reader (Tecan).

\section{Determination of the $K_{\mathrm{D}}$ of the antibodies}

For the determination of the antibody bound fraction (BF) of a modified nucleoside, six samples of an equimolar mixture of the 
modified nucleoside with an internal standard (mostly the unmodified nucleoside) were prepared at six different concentrations (concentrations ranged from 75 to $250 \mu \mathrm{M}$ ). In order to maintain a constant ratio between the amount of the modified nucleoside and the internal standard, the dilutions were prepared out of a premixed stock solution with a concentration of $0.5 \mathrm{mM}$ for each nucleoside. A volume of $20 \mu \mathrm{L}$ of each of these mixtures were pipetted to $100 \mu \mathrm{L}$ PBS (=Input sample) and to $100 \mu \mathrm{L}$ PBS containing exactly the same amount of antibody for each sample $(\sim 150 \mu \mathrm{g})$ leading to initial nucleoside concentrations in the range of 12.5 to $41.7 \mu \mathrm{M}$. After incubation of the mixtures for $2 \mathrm{~h}$ at $4^{\circ} \mathrm{C}$, the unbound nucleosides of the antibody-containing samples were separated by centrifugation ( $2 \mathrm{~min}, 14,000 \mathrm{~g}$ ) using a $10 \mathrm{kDa}$ cut-off spin filter (Roti-Spin MINI, Roth). A volume of $40 \mu \mathrm{L}$ of each input and filtrate-sample was then applied to the HPLC with one replicate (see HPLC analysis of nucleosides). The two peaks of each chromatogram were integrated. The peak area of the modified nucleoside normalized to the peak area of the internal standard eventually gave the normalized peak areas of the modified nucleoside in the input sample (nucleoside input, $\mathrm{NI}$ ) and in the filtrate of the antibody sample (nucleoside-antibody, NA) at the various concentrations. The antibody-bound fraction $(\mathrm{BF})$ of the modified nucleoside can then be calculated by: $\mathrm{BF}=(\mathrm{NI}-\mathrm{NA}) / \mathrm{NI}$, which can be used to derive the concentrations of bound ([AbN]) and free nucleoside ([N]) from the initial nucleoside concentration $\left(\left[\mathrm{N}_{0}\right]\right):[\mathrm{AbN}]=\mathrm{BF} \times\left[\mathrm{N}_{0}\right]$ and $[\mathrm{N}]=(1-\mathrm{BF})$ $\times\left[N_{0}\right]$. To get a first estimation of the values for $K_{D}$ and the maximal concentration of binding sites of the antibody ( $\left.\left[B_{\text {max }}\right]\right)$, the ratio $[\mathrm{AbN}] /[\mathrm{N}]$ was plotted against $[\mathrm{AbN}]$ to obtain a Scatchard plot (Scatchard 1949). From this, the $K_{D}$ (dissociation constant) was estimated using the negative reciprocal value of the slope of the resulting regression line. The maximal concentration of binding sites is represented by the intersection point of the regression line with the $x$-axis. These estimates were then used to describe the binding with the following model:

$$
[\mathrm{AbN}]=\frac{\left[\mathrm{B}_{\max }\right] *[\mathrm{~N}]}{K_{\mathrm{D}}+[\mathrm{N}]} .
$$

To enhance the accuracy of the model-parameters, the measured data points were fitted with nonlinear regression, whereby the residual sum-of-squares between model and measured data points was minimized using Excel solver. Finally, the 95\%-confidence limits of the model parameters were determined via the model comparison-approach ( $F$-test).

\section{HPLC analysis of nucleosides}

The nucleosides were resolved on a Hypercarb-column (5 $\mu \mathrm{m}$, $100 \times 2.1$; Thermo Scientific) using the HPLC-system "WellChrom" from Knauer, equipped with Pump K-1001, Diode Array Detector K-2800, column oven and a Vacuum Degasser from Techlab GmbH (Germany). The experiments were done, detecting at wavelengths ranging from 260 to $280 \mathrm{~nm}$. The resulting chromatograms were analyzed with the software ChromGate Client/Server Vers. 3.1.7. Depending on the particular nucleosides, three different gradients (purinfast2, pyrimidinfast2, pyrimidin50\%ACN) of the buffers $\mathrm{A}\left(50 \mathrm{mM} \mathrm{NH} \mathrm{CH}_{3} \mathrm{CO}_{2}, \mathrm{pH} 5.0\right)$, B (20\% 50 mM NH${ }_{4} \mathrm{CH}_{3} \mathrm{CO}_{2}, \mathrm{pH} \mathrm{5.0/80 \%} \mathrm{acetonitrile)} \mathrm{and} \mathrm{C}$ (50\% acetonitrile) were applied at different temperatures $\left(25^{\circ} \mathrm{C}\right.$, $\left.55^{\circ} \mathrm{C}\right)$ and flow rates $(0.2 \mathrm{~mL} / \mathrm{min}, 0.25 \mathrm{~mL} / \mathrm{min})$. For details see the gradient tables in the Supplemental Information. For quantifying the percentage changes of the nucleoside concentrations between different samples, an equimolar amount of an internal standard (mostly the unmodified nucleoside) was added to the solution of the modified nucleoside. The peak area of the modified nucleoside was then normalized to the internal standard to correct for loading errors and/or unspecific binding during processing.

\section{Dot blot}

A total of $8 \mu \mathrm{g}$ of RNA-oligo (Dharmacon) were spotted on a nylon membrane. The RNA was EDC [1-ethyl-3-(3-dimethylaminopropyl) carbodiimide hydrochloride] cross-linked to the membrane. When using BSA-nucleotide conjugates, $20 \mu \mathrm{g}$ was spotted, and the membrane was baked at $80^{\circ} \mathrm{C}$ for $1 \mathrm{~h}$ to crosslink. In both cases, the membrane was blocked in $1 \times$ TBS-T (150 mM NaCl, $10 \mathrm{mM}$ Tris, pH 8.0, 0.1\% Tween) containing 5\% skimmed milk for $1 \mathrm{~h}$ at $4^{\circ} \mathrm{C}$. The first antibody (hybridoma) was diluted 1:5 in a 5\% skimmed milk solution in TBS-T and incubated overnight at $4{ }^{\circ} \mathrm{C}$, shaking. The secondary antibody $(\alpha-$ mouse and $\alpha$-rat [Licor]) was diluted 1:10,000 in TBS-T containing $5 \%$ skimmed milk and incubated for $1 \mathrm{~h}$. The documentation was conducted using the Odyssey scanner system (LI-COR Biosciences).

\section{RNA immunoprecipitation}

Total RNA from HEK293T cells was isolated using TRlzol (Thermo Fisher Scientific). Several titration experiments have been conducted for the optimization of the RNA immunoprecipitations. Thus, wide ranges of RNA, antibody and buffer concentrations and amounts are given in this protocol. Two different protocol setups for the RNA immunoprecipitations were tested for these antibodies. For a part of the experiments, $0.1-100 \mu \mathrm{g}$ of the respective purified antibody were coupled overnight at $4^{\circ} \mathrm{C}$ to $35 \mu \mathrm{L}$ Protein G Sepharose beads (GE Healthcare). The coupled beads were washed thrice in RNA-IP buffer (150-750 mM LiCl, $0.5 \%$ NP-40, $10 \mathrm{mM}$ Tris-HCl, $\mathrm{pH} 7.5)$ or NET buffer $(50 \mathrm{mM}$ Tris, $\mathrm{pH} 7.5,150 \mathrm{mM} \mathrm{NaCl}, 5 \mathrm{mM}$ EDTA, 0.5\% NP-40, 10\% glycerol). Using $0.1-100 \mu \mathrm{g}$ of the total RNA $(\sim 1 \mu \mathrm{g} / \mu \mathrm{L})$ or $0.5-1 \mathrm{nmol}$ of the RNA-oligos (ACGCGUm ${ }^{6}$ ACUUGA, ACGCGUAm ${ }^{5}$ CUUGA,

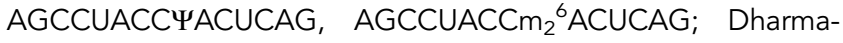
con), the immunoprecipitation was conducted for $2 \mathrm{~h}$ in 0.5-1 $\mathrm{mL}$ RNA-IP buffer. For the other setup, the antibody was incubated with the RNA in RNA-IP buffer for $2 \mathrm{~h}$. Protein G Sepharose beads were added and incubated for an additional $2 \mathrm{~h}$. For the nucleotide-competition assay, $5 \mu \mathrm{M}-5 \mathrm{mM}$ nucleotide (end concentration) was added and incubated for one additional hour. The setups were then washed once each with RNA-IP buffer, wash buffer I (RNA-IP buffer with 300-1000 mM LiCl) and wash buffer II (RNA-IP buffer with 450-1500 mM LiCl) or with NET buffer and twice with NET wash buffer (NET buffer with an additional $150 \mathrm{mM} \mathrm{NaCl}$ ). For isolation of the RNA from the beads, either TRIzol was used or the immune precipitated RNA was eluted from the beads by adding 250-500 $\mu \mathrm{M}$ nucleoside in $150 \mu \mathrm{L}$ RIP buffer to the beads and incubating another $1 \mathrm{~h}$ at $4^{\circ} \mathrm{C}$, shaking. The RNA was precipitated using TRIzol afterwards. 


\section{In vitro transcription with ${ }^{32} \mathrm{P}$-labeled and modified NTPs, immune precipitation, and digestion}

DNA oligos with different lengths (880, 100, and $50 \mathrm{bp}$ ) were in vitro transcribed in four different setups. For the first two transcriptions, modified NTPs of interest in different ratios of the total NTPs were used. In one of them, additional ${ }^{32}$ P-UTP was added. The control setups were transcribed using unmodified NTPs and for the radioactive sample, ${ }^{32} \mathrm{P}$-ATP was used. The four different samples were then DNase-digested and purified using the MEGAclear Transcription Clean-Up Kit (Ambion). For the cold samples, the concentration was determined using a NanoDrop Photometer, for the hot samples, the cpm-values were determined using the Cerenkov setting at a Scintillation-counter. The different RNA-solutions were then mixed to obtain equal cpm-values as well as same amounts $(1.25-8 \mu \mathrm{g})$ for the modified and unmodified samples. These setups were then used for immune precipitation (for protocol: see RNA Immunoprecipitation). The precipitated RNA was digested using Nuclease P1 overnight at $37^{\circ} \mathrm{C}$. The single nucleotides were afterwards analyzed via 1D thin layer chromatography.

\section{Thin layer chromatography (TLC)}

The digestion with nuclease P1 and the TLC was conducted as described earlier (e.g., Grosjean et al. 2004). The digested RNA was spotted on a TLC-plate which ran in $66 \%$ isobutyric acid and $1 \%$ conc. ammonia for 3-4 h. After drying, the signals were detected by exposure to a screen and scanning using a Phospho-imager (PMI, Bio-Rad).

\section{Northern blot}

Northern blot analysis was carried out as described earlier (Pall and Hamilton 2008). Briefly, the RNA was complemented with a $2 \times$ RNA loading dye (formamide with bromophenol blue and $x y-$ lene blue) and separated on 6\%-12\% Urea gels (Rotiphorese, Roth) and semi-dry blotted onto a nylon membrane. The RNA was then either EDC cross-linked to the membrane and/or cross-linked via UV, depending on the size of the RNA of interest and hybridized overnight at $50^{\circ} \mathrm{C}$. ${ }^{32} \mathrm{P}$-labeled $5^{\prime}$-GACGCTCA GACAGGCGTAGCCC-3' was used for $5.8 \mathrm{~S}$ rRNA and 5'-CAT GCATGGCTTAATCTTTGAGACAAGC-3' for $18 \mathrm{~S}$ rRNA detection. To detect GFP mRNA, a probe with the following sequence was used: 5'-CCTTGAAGAAGATGGTGC-3'. The blot was then washed twice with wash buffer I ( $5 \times$ SSC, $1 \%$ SDS) and once with wash buffer II (1× SSC, $1 \%$ SDS). Signals were detected and documented using a Phospho-imager (PMI, Bio-Rad).

\section{miCLIP analysis}

The miCLIP experiments were executed largely following the protocol of (Grozhik et al. 2017). The fragmentation of the total RNA was performed with $\mathrm{ZnCl}_{2}$ at $94^{\circ} \mathrm{C}$ for 5 min as it is described in (Dominissini et al. 2013). The fragmented total RNA was incubated with the antibody of interest for $2 \mathrm{~h}$, rotating and afterwards UV-cross-linked, using $254 \mathrm{~nm}$ and $150 \mathrm{~mJ} / \mathrm{cm}^{2}$. Using protein $\mathrm{G}$ dynabeads (Invitrogen), the cross-linked RNA was precipitated for $2 \mathrm{~h}$ while rotating. After several washing steps, the RNA, at- tached to the antibody and beads was dephosphorylated and $5^{\prime}$-radiolabeled with $\gamma^{3}{ }^{32}$ P-ATP. The beads were then resuspended in SDS-loading dye for elution. After SDS-PAGE, the gel was wet-blotted onto a nitrocellulose membrane at $90 \mathrm{~V}$ for $90 \mathrm{~min}$. The radioactive signals were then detected using a Phosphoimager (PMI, Bio-Rad).

\section{Western blot analysis}

For performing western blot analysis, proteins were transferred onto a nitrocellulose membrane (GE Healthcare) using Towbin blotting buffer (192 mM glycine, $25 \mathrm{mM}$ Tris $/ \mathrm{HCl} \mathrm{pH} \mathrm{8.6,} \mathrm{20 \%}$ methanol). Membranes were blocked in $1 \times$ TBST $(150 \mathrm{mM}$ $\mathrm{NaCl}, 10 \mathrm{mM}$ Tris/ $\mathrm{HCl} \mathrm{pH} 8,0.1 \%$ Tween 20) containing 5\% skimmed milk for $1 \mathrm{~h}$ at $4{ }^{\circ} \mathrm{C}$. After incubation with first and secondary antibody, the membrane was washed three times with $1 \times$ TBST. $\alpha-\alpha$ Tubulin (mouse, Sigma, clone DM1A) and $\alpha$-METTL3 (rabbit, Proteintech Europe) were used as primary and $\alpha$-mouse and $\alpha$-rabbit (Licor) were used as secondary antibodies. The documentation was conducted using the Odyssey scanner system (LI-COR Biosciences).

\section{Immunofluorescence staining of human cells}

C643 wild-type (WT) and METTL3 knockout (KO) cells were seeded on coverslips. The immunofluorescence experiments were conducted as described previously (Schraivogel et al. 2015). In short, fixation was performed, using 3.7\% PFA in PBS and stopped with $7.5 \mathrm{mg} / \mathrm{mL}$ glycine in PBS. Permeabilization was done with $0.2 \%$ Triton-X 100 in PBS. After blocking in $1 \%$ BSA in PBS with $0.05 \%$ Triton X-100, the first and secondary antibodies were incubated in blocking buffer. After incubation with the antibodies, cells were mounted using Prolong Gold containing DAPI (Thermo Fisher Scientific-Life Technologies). Confocal microscopy was done on a TCSSP8 (Leica Microsystems) equipped with acousto-optical beam splitter, $405 \mathrm{~nm}$ laser (for DAPI) and argon laser (488 $\mathrm{nm}$ for $\alpha$-rat and $\alpha$-rabbit Alexa 488 [Invitrogen]). Signal intensity was quantified using ImageJ (Wayne Rasband, NIH).

\section{Immunostaining and fluorescence of MTF cells}

Mouse tail fibroblasts MTF-line3 (Guy et al. 2001) were seeded on gelatin coated glass coverslips $1 \mathrm{~d}$ prior immunostaining. To test the ability of the different antibody clones to detect genomic 5-methylcytosine, a previously described immunofluorescence staining protocol (Ludwig et al. 2017) was used. In brief, cells were fixed for $10 \mathrm{~min}$ with $3.7 \%$ formaldehyde, permeabilized for 20 min with $0.5 \%$ Triton X-100 and incubated with ice-cold methanol for $5 \mathrm{~min}$. Afterwards, cells were incubated with or without $10 \mu \mathrm{g} / \mathrm{mL}$ RNaseA and blocked in $0.2 \%$ fish skin gelatin each for $30 \mathrm{~min}$ at $37^{\circ} \mathrm{C}$. Cells were incubated with the primary antibodies for $70 \mathrm{~min}$ at $37^{\circ} \mathrm{C}$. The primary antibody mix contained $2 \%$ BSA, 1× DNase I Buffer (10 mM Tris- $\mathrm{HCl}, 2.5 \mathrm{mM} \mathrm{MgCl}_{2}, 0.5$ $\mathrm{mM} \mathrm{CaCl} 2$ ), $25 \mathrm{U} / \mathrm{mL}$ DNase I (Sigma Aldrich) and the respective mouse anti-m ${ }^{5} \mathrm{C}$ clones, 28F6, 31B10, and 32E2 or the commercially available clone 33D3 (Active Motif). All clones were tested in dilutions of 1:100, 1:250 and 1:500 with an assumed 
concentration of $1 \mu \mathrm{g} / \mu \mathrm{L}$. As control, samples were incubated with primary antibody mix without antibody (" $2^{\circ}$ only"). After incubation with the primary antibody, cells were washed three times with PBS-TE (0.01\% Tween, $1 \mathrm{mM}$ EDTA) and incubated with the secondary Alexa Fluor 488 conjugated goat anti-mouse-lgG antibody (1:250, The Jackson Laboratory) for $45 \mathrm{~min}$ at room-temperature. After washing with PBS-T (0.01\% Tween), cells were counterstained with DAPI ( $1 \mu \mathrm{g} / \mathrm{mL}$, Sigma Aldrich) and mounted in Moviol (Sigma Aldrich). To control for RNaseA activity, cells were treated as described for the immunostaining, with the difference that all antibodies in the mix were omitted and instead of DAPI, cells were stained with propidium iodide $(1 \mu \mathrm{g} / \mathrm{mL})$. The respective signals were quantified by imaging cells with the Operetta high-content screening system (PerkinElmer), equipped with a Xenon fiber optic light source, a $20 \times$ long/0.45 NA objective, and 360-400, 460-490, and 520-550 nm excitation-as well as 410-480, 500-550, and 560-630 emission filters. Nuclei were identified by their DAPI or propidium iodide signal and in DAPI and $\mathrm{m}^{5} \mathrm{C}$ stained nuclei the respective Alexa Fluor 488 signal was calculated. Intensities of stained nuclei were normalized by dividing all values by the mean nuclear Alexa Fluor 488 intensity of the " $2^{\circ}$ only" control. Normalized nuclear Alexa Fluor 488 values and mean nuclear propidium iodide values were plotted using $\mathrm{R}$ Studio. Also, statistical significance was tested with $\mathrm{R}$ Studio. Confocal $Z$ stacks of immunostained cells were acquired with an Ultra-View VoX spinning disc microscope (PerkinElmer, UK) controlled by Volocity 6.3 (PerkinElmer) and equipped with a $60 \times / 1.45$ NA Planapochromat oil immersion objective (voxel size, $0.12 \times 0.12 \times 0.5 \mu \mathrm{m}$; Nikon) and a cooled 14-bit CCD camera (cat. no. C9100-50, Hamamatsu Photonics K.K.). Z-stacks were assembled into maximum Z-projections using ImageJ.

\section{Cell culture of MEF cells}

Mouse embryonic fibroblast (MEF) cells were cultured in Dulbecco's modified Eagle's medium (DMEM, GIBCO) supplemented with $10 \%(\mathrm{v} / \mathrm{v}$ ) fetal bovine serum (FBS), $1000 \mathrm{U} / \mathrm{mL}$ penicillin-streptomycin (GIBCO), and $10 \mathrm{mM} \mathrm{HEPES,} \mathrm{pH} 7.4$ (GIBCO) at $37^{\circ} \mathrm{C}$ in $10 \% \mathrm{CO}_{2}$. To establish $\mathrm{WTAP}^{-1-}$ MEF cells, retrovirus (mock or Cre) infection of MEFs was performed as described previously. Two days after virus infection, cells were diluted following trypsination and cultured in the presence of puromycin $(1 \mu \mathrm{g} / \mathrm{mL})$ for an dditional $3 \mathrm{~d}$ to select infected cell populations.

\section{FACS sample preparation and analysis}

After harvesting MEF WT and WTAP KO cells, they were washed with PBS. Cells were fixed with of $2 \%$ Formaldehyde in PBS for $15 \mathrm{~min}$ at RT. Subsequently, the cells were permeabilized with $0.5 \%$ saponin buffer in PBS. The first antibody was applied for 90 min at RT in 0.5\% Saponin buffer in PBS. Along the generated $\alpha-m^{6} A$ antibody clones, the $\alpha-m^{6} A$ antibody from Abcam (ab151230) was applied. After washing in PBS, the cells were incubated for 30 min at RT with the second antibody (Alex647-conjugated goat $\alpha$-rat lgG, BioLegend, poly4054 or rabbit lgG, Invitrogen) in $0.5 \%$ Saponin buffer in PBS. For detection of the biotinylated antibodies, APC-conjugated streptavidin was applied. To stain WTAP, cells were fixed and permeabilized by using the Foxp3/Transcription Factor staining buffer set (eBioscience) according to manufacturer's instructions. Anti-WTAP antibody (Proteintech, 60188) and FITC-conjugated goat antibody $\alpha$-mouse IgG (BD Biosciences) were applied. After staining, cells were acquired on a FACS Canto II (BD Biosciences) device and samples were analyzed with FlowJo software.

\section{SUPPLEMENTAL MATERIAL}

Supplemental material is available for this article.

\section{ACKNOWLEDGMENTS}

We thank S. Ammon and C. Friederich for technical support. This work was supported by the Deutsche Forschungsgemeinschaft (DFG) grant SPP 1784/1 and 2 and the Bavarian SystemsBiology Network (BioSysNet) to G.M.; and by DFG grant CA 198/10-1 to M.C.C.

Received April 22, 2020; accepted June 30, 2020.

\section{REFERENCES}

Amort T, Rieder D, Wille A, Khokhlova-Cubberley D, Riml C, Trixl L, Jia XY, Micura R, Lusser A. 2017. Distinct 5-methylcytosine profiles in poly(A) RNA from mouse embryonic stem cells and brain. Genome Biol 18: 1. doi:10.1186/s13059-016-1139-1

Batista PJ, Molinie B, Wang J, Qu K, Zhang J, Li L, Bouley DM, Lujan E, Haddad B, Daneshvar K, et al. 2014. m ${ }^{6}$ A RNA modification controls cell fate transition in mammalian embryonic stem cells. Cell Stem Cell 15: 707-719. doi:10.1016/j.stem.2014.09.019

Bergquist PL, Matthews RE. 1962. Occurrence and distribution of methylated purines in the ribonucleic acids of subcellular fractions. Biochem J 85: 305-313. doi:10.1042/bj0850305

Bohnsack MT, Sloan KE. 2018. Modifications in small nuclear RNAs and their roles in spliceosome assembly and function. Biol Chem 399: 1265-1276. doi:10.1515/hsz-2018-0205

Bringmann P, Luhrmann R. 1987. Antibodies specific for $N^{6}$-methyladenosine react with intact snRNPs U2 and U4/U6. FEBS Lett 213: 309-315. doi:10.1016/0014-5793(87)81512-0

Carlile TM, Rojas-Duran MF, Zinshteyn B, Shin H, Bartoli KM, Gilbert WV. 2014. Pseudouridine profiling reveals regulated mRNA pseudouridylation in yeast and human cells. Nature 515: 143-146. doi:10.1038/nature13802

Casas-Delucchi CS, van Bemmel JG, Haase S, Herce HD, Nowak D, Meilinger D, Stear JH, Leonhardt H, Cardoso MC. 2012. Histone hypoacetylation is required to maintain late replication timing of constitutive heterochromatin. Nucleic Acids Res 40: 159-169. doi:10.1093/nar/gkr723

Cecchini JP, Miassod R. 1979. Studies on the methylation of cytoplasmic ribosomal RNA from cultured higher plant cells. Eur J Biochem 98: 203-214. doi:10.1111/j.1432-1033.1979.tb13178.x

Coots RA, Liu XM, Mao Y, Dong L, Zhou J, Wan J, Zhang X, Qian SB. 2017. $\mathrm{m}^{6} \mathrm{~A}$ facilitates elF4F-independent mRNA translation. Mol Cell 68: 504-514 e507. doi:10.1016/j.molcel.2017.10.002

Dominissini D, Moshitch-Moshkovitz S, Schwartz S, Salmon-Divon M, Ungar L, Osenberg S, Cesarkas K, Jacob-Hirsch J, Amariglio N, Kupiec $M$, et al. 2012. Topology of the human and mouse $m^{6} A$ RNA methylomes revealed by $\mathrm{m}^{6} \mathrm{~A}$-seq. Nature 485: 201-206. doi:10.1038/nature11112

Dominissini D, Moshitch-Moshkovitz S, Salmon-Divon M, Amariglio N, Rechavi G. 2013. Transcriptome-wide mapping of $\mathrm{N}^{6}$-methyladenosine by $\mathrm{m}^{6} \mathrm{~A}$-seq based on immunocapturing 
and massively parallel sequencing. Nat Protoc 8: 176-189. doi:10 $.1038 /$ nprot.2012.148

Edelheit S, Schwartz S, Mumbach MR, Wurtzel O, Sorek R. 2013. Transcriptome-wide mapping of 5-methylcytidine RNA modifications in bacteria, archaea, and yeast reveals $\mathrm{m}^{5} \mathrm{C}$ within archaeal mRNAs. PLoS Genet 9: e1003602. doi:10.1371/journal.pgen .1003602

Erlanger BF, Beiser SM. 1964. Antibodies specific for ribonucleosides and ribonucleotides and their reaction with DNA. Proc Natl Acad Sci 52: 68-74. doi:10.1073/pnas.52.1.68

Feederle R, Schepers A. 2017. Antibodies specific for nucleic acid modifications. RNA Biol 14: 1089-1098. doi:10.1080/15476286 .2017 .1295905

Fu Y, Dominissini D, Rechavi G, He C. 2014. Gene expression regulation mediated through reversible $\mathrm{m}^{6} \mathrm{~A}$ RNA methylation. Nat Rev Genet 15: 293-306. doi:10.1038/nrg3724

Grosjean H, Keith G, Droogmans L. 2004. Detection and quantification of modified nucleotides in RNA using thin-layer chromatography. Methods Mol Biol 265: 357-391. doi:10.1385/1-59259775-0:357

Grozhik AV, Linder B, Olarerin-George AO, Jaffrey SR. 2017. Mapping $\mathrm{m}^{6} \mathrm{~A}$ at individual-nucleotide resolution using crosslinking and immunoprecipitation (miCLIP). Methods Mol Biol 1562: 55-78. doi:10.1007/978-1-4939-6807-7_5

Grozhik AV, Olarerin-George AO, Sindelar M, Li X, Gross SS, Jaffrey SR. 2019. Antibody cross-reactivity accounts for widespread appearance of $\mathrm{m}^{1} \mathrm{~A}$ in $5^{\prime} \mathrm{UTR}$. Nat Commun 10: 5126. doi:10.1038/s41467-019-13146-w

Guy J, Hendrich B, Holmes M, Martin JE, Bird A. 2001. A mouse Mecp2-null mutation causes neurological symptoms that mimic Rett syndrome. Nat Genet 27: 322-326. doi:10.1038/85899

Helm M, Motorin Y. 2017. Detecting RNA modifications in the epitranscriptome: predict and validate. Nat Rev Genet 18: 275-291. doi:10.1038/nrg.2016.169

Helm M, Lyko F, Motorin Y. 2019. Limited antibody specificity compromises epitranscriptomic analyses. Nat Commun 10: 5669. doi:10.1038/s41467-019-13684-3

Huang T, Chen W, Liu J, Gu N, Zhang R. 2019. Genome-wide identification of mRNA 5-methylcytosine in mammals. Nat Struct Mol Biol 26: 380-388. doi:10.1038/s41594-019-0218-x

Hussain S, Sajini AA, Blanco S, Dietmann S, Lombard P, Sugimoto Y, Paramor M, Gleeson JG, Odom DT, Ule J, et al. 2013. NSun2-mediated cytosine-5 methylation of vault noncoding RNA determines its processing into regulatory small RNAs. Cell Rep 4: 255-261. doi:10.1016/j.celrep.2013.06.029

Jones PA. 2012. Functions of DNA methylation: islands, start sites, gene bodies and beyond. Nat Rev Genet 13: 484-492. doi:10 $.1038 / \mathrm{nrg} 3230$

Ke S, Alemu EA, Mertens C, Gantman EC, Fak JJ, Mele A, Haripal B, Zucker-Scharff I, Moore MJ, Park CY, et al. 2015. A majority of $\mathrm{m}^{6} \mathrm{~A}$ residues are in the last exons, allowing the potential for $3^{\prime}$ UTR regulation. Genes Dev 29: 2037-2053. doi:10.1101/gad.269415.115

Ke S, Pandya-Jones A, Saito Y, Fak JJ, Vagbo CB, Geula S, Hanna JH, Black DL, Darnell JE Jr,Darnell RB. 2017. $\mathrm{m}^{6}$ A mRNA modifications are deposited in nascent pre-mRNA and are not required for splicing but do specify cytoplasmic turnover. Genes Dev 31: 9901006. doi:10.1101/gad.301036.117

Kohler G, Milstein C. 1975. Continuous cultures of fused cells secreting antibody of predefined specificity. Nature 256: 495-497. doi:10.1038/256495a0

Legrand C, Tuorto F, Hartmann M, Liebers R, Jacob D, Helm M, Lyko F. 2017. Statistically robust methylation calling for wholetranscriptome bisulfite sequencing reveals distinct methylation patterns for mouse RNAs. Genome Res 27: 1589-1596. doi:10 $.1101 /$ gr.210666.116
Li X, Zhu P, Ma S, Song J, Bai J, Sun F, Yi C. 2015. Chemical pulldown reveals dynamic pseudouridylation of the mammalian transcriptome. Nat Chem Biol 11: 592-597. doi:10.1038/nchem bio.1836

Li X, Xiong X, Zhang M, Wang K, Chen Y, Zhou J, Mao Y, Lv J, Yi D, Chen XW, et al. 2017. Base-resolution mapping reveals distinct $\mathrm{m}^{1} \mathrm{~A}$ methylome in nuclear- and mitochondrial-encoded transcripts. Mol Cell 68: 993-1005 e1009. doi:10.1016/j.molcel 2017.10.019

Linder B, Grozhik AV, Olarerin-George AO, Meydan C, Mason CE, Jaffrey SR. 2015. Single-nucleotide-resolution mapping of $\mathrm{m}^{6} A$ and $\mathrm{m}^{6} \mathrm{~A}_{\mathrm{m}}$ throughout the transcriptome. Nat Methods 12: 767 772. doi:10.1038/nmeth.3453

Littlefield JW, Dunn DB. 1958. Natural occurrence of thymine and three methylated adenine bases in several ribonucleic acids. Nature 181: 254-255. doi:10.1038/181254aO

Liu J, Yue Y, Han D, Wang X, Fu Y, Zhang L, Jia G, Yu M, Lu Z, Deng X, et al. 2014. A METTL3-METTL14 complex mediates mammalian nuclear RNA $N^{6}$-adenosine methylation. Nat Chem Biol 10: 93-95. doi:10.1038/nchembio.1432

Lovejoy AF, Riordan DP, Brown PO. 2014. Transcriptome-wide mapping of pseudouridines: pseudouridine synthases modify specific mRNAs in S. cerevisiae. PLoS ONE 9: e110799. doi:10.1371/jour nal.pone.0110799

Ludwig AK, Zhang P, Hastert FD, Meyer S, Rausch C, Herce HD, Muller U, Lehmkuhl A, Hellmann I, Trummer C, et al. 2017. Binding of MBD proteins to DNA blocks Tet1 function thereby modulating transcriptional noise. Nucleic Acids Res 45: 24382457. doi:10.1093/nar/gkw1197

Maity A, Das B. 2016. N6-methyladenosine modification in mRNA: machinery, function and implications for health and diseases. FEBS J 283: 1607-1630. doi:10.1111/febs.13614

Matera AG, Terns RM, Terns MP. 2007. Non-coding RNAs: lessons from the small nuclear and small nucleolar RNAs. Nat Rev Mol Cell Biol 8: 209-220. doi:10.1038/nrm2124

Meyer KD, Jaffrey SR. 2017. Rethinking $m^{6} A$ readers, writers, and erasers. Annu Rev Cell Dev Biol 33: 319-342. doi:10.1146/annurevcellbio-100616-060758

Meyer KD, Saletore Y, Zumbo P, Elemento O, Mason CE, Jaffrey SR. 2012. Comprehensive analysis of mRNA methylation reveals enrichment in 3'UTRs and near stop codons. Cell 149: 1635-1646. doi:10.1016/j.cell.2012.05.003

Meyer KD, Patil DP, Zhou J, Zinoviev A, Skabkin MA, Elemento O, Pestova TV, Qian SB, Jaffrey SR. 2015. 5'UTR $\mathrm{m}^{6} \mathrm{~A}$ promotes cap-independent translation. Cell 163: 999-1010. doi:10.1016/j .cell.2015.10.012

Motorin Y, Helm M. 2011. RNA nucleotide methylation. Wiley Interdiscip Rev RNA 2: 611-631. doi:10.1002/wrna.79

Pall GS, Hamilton AJ. 2008. Improved northern blot method for enhanced detection of small RNA. Nat Protoc 3: 1077-1084. doi:10.1038/nprot.2008.67

Plescia OJ, Braun W. 1967. Nucleic acids as antigens. Adv Immunol 6: 231-252. doi:10.1016/S0065-2776(08)60523-4

Polikanov YS, Melnikov SV, Soll D, Steitz TA. 2015. Structural insights into the role of rRNA modifications in protein synthesis and ribosome assembly. Nat Struct Mol Biol 22: 342-344. doi:10.1038/ nsmb.2992

Safra M, Sas-Chen A, Nir R, Winkler R, Nachshon A, Bar-Yaacov D, Erlacher M, Rossmanith W, Stern-Ginossar N, Schwartz S. 2017. The $\mathrm{m}^{1} \mathrm{~A}$ landscape on cytosolic and mitochondrial mRNA at single-base resolution. Nature 551: 251-255. doi:10.1038/ nature24456

Scatchard G. 1949. Equilibrium in non-electrolyte mixtures. Chem Rev 44: 7-35. doi:10.1021/cr60137a002 
Schraivogel D, Schindler SG, Danner J, Kremmer E, Pfaff J, Hannus S, Depping R, Meister G. 2015. Importin- $\beta$ facilitates nuclear import of human GW proteins and balances cytoplasmic gene silencing protein levels. Nucleic Acids Res 43: 7447-7461. doi:10.1093/ nar/gkv705

Schwartz S, Bernstein DA, Mumbach MR, Jovanovic M, Herbst RH, Leon-Ricardo BX, Engreitz JM, Guttman M, Satija R, Lander ES, et al. 2014. Transcriptome-wide mapping reveals widespread dynamic-regulated pseudouridylation of ncRNA and mRNA. Cell 159: 148-162. doi:10.1016/j.cell.2014.08.028

Slama K, Galliot A, Weichmann F, Hertler J, Feederle R, Meister G, Helm M. 2019. Determination of enrichment factors for modified RNA in MeRIP experiments. Methods 156: 102-109. doi:10 $.1016 / j$.ymeth.2018.10.020

Squires JE, Patel HR, Nousch M, Sibbritt T, Humphreys DT, Parker BJ, Suter CM, Preiss T. 2012. Widespread occurrence of 5-methylcytosine in human coding and non-coding RNA. Nucleic Acids Res 40: 5023-5033. doi:10.1093/nar/gks144

Trixl L, Lusser A. 2019. The dynamic RNA modification 5-methylcytosine and its emerging role as an epitranscriptomic mark. Wiley Interdiscip Rev RNA 10: e1510. doi:10.1002/wrna.1510
Yang $Y$, Fan $X$, Mao M, Song $X$, Wu P, Zhang Y, Jin Y, Yang Y, Chen LL, Wang Y, et al. 2017. Extensive translation of circular RNAs driven by $N^{6}$-methyladenosine. Cell Res 27: 626-641. doi:10.1038/cr.2017.31

Yue Y, Liu J, He C. 2015. RNA $N^{6}$-methyladenosine methylation in post-transcriptional gene expression regulation. Genes Dev 29: 1343-1355. doi:10.1101/gad.262766.115

Zaringhalam M, Papavasiliou FN. 2016. Pseudouridylation meets next-generation sequencing. Methods 107: 63-72. doi:10.1016/ j.ymeth.2016.03.001

Zhao BS, Roundtree IA, He C. 2017. Post-transcriptional gene regulation by mRNA modifications. Nat Rev Mol Cell Biol 18: 31-42. doi:10.1038/nrm.2016.132

Zhou KI, Clark WC, Pan DW, Eckwahl MJ, Dai Q, Pan T. 2018. Pseudouridines have context-dependent mutation and stop rates in high-throughput sequencing. RNA Biol 15: 892-900. doi:10 .1080/15476286.2018.1462654

Zhou KI, Shi H, Lyu R, Wylder AC, Matuszek Z, Pan JN, He C, Parisien M, Pan T. 2019. Regulation of co-transcriptional premRNA splicing by $\mathrm{m}^{6} \mathrm{~A}$ through the low-complexity protein hnRNPG. Mol Cell 76: 70-81.e79. doi:10.1016/j.molcel .2019.07.005 

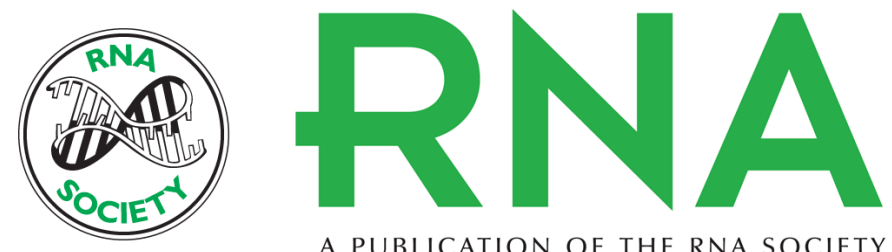

A PUBLICATION OF THE RNA SOCIETY

\section{Validation strategies for antibodies targeting modified ribonucleotides}

Franziska Weichmann, Robert Hett, Aloys Schepers, et al.

RNA 2020 26: 1489-1506 originally published online July 7, 2020

Access the most recent version at doi:10.1261/rna.076026.120

Supplemental Material

References

Creative Commons License

Email Alerting Service
http://rnajournal.cshlp.org/content/suppl/2020/07/07/rna.076026.120.DC1

This article cites 57 articles, 6 of which can be accessed free at: http://rnajournal.cshlp.org/content/26/10/1489.full.html\#ref-list-1

This article is distributed exclusively by the RNA Society for the first 12 months after the full-issue publication date (see http://rnajournal.cshlp.org/site/misc/terms.xhtml). After 12 months, it is available under a Creative Commons License (Attribution-NonCommercial 4.0 International), as described at http://creativecommons.org/licenses/by-nc/4.0/.

Receive free email alerts when new articles cite this article - sign up in the box at the top right corner of the article or click here. 